\title{
Both vicariance and dispersal have shaped the genetic structure of Eastern Mediterranean \\ Euphorbia myrsinites (Euphorbiaceae)
}

\author{
Diplomarbeit \\ Zur Erlangung des akademischen Grades \\ Magister der Naturwissenschaften
}

Moritz Falch

00916557

Studiengang

Lehramt: Biologie und Umweltkunde - Deutsch

C 190445333

Eingereicht am Institut für Botanik

Forschungsgruppe Evolutionäre Systematik

bei

Assoz. Prof. Dr. Božo Frajman 


\section{Danksagung}

Diese Arbeit hätte nicht entstehen können ohne die finanzielle und moralische Unterstützung meiner Eltern. Danke auch dafür, dass ihr mich immer ermutigt habt, meinen eigenen Weg zu gehen, anderen Falls wäre ich nie auf der Exkursion in Montenegro gelandet, die ganz am Anfang steht.

Danke meiner lieben Anna und Sona Mae, für die Zeit, Liebe und Motivation, die ihr mir schenkt und dass ihr meine Launen ertragt.

Danke Božo für die Geduld, die Motivation und die gute Betreuung. Ohne dein stetiges Antreiben wäre ich nie fertig geworden.

Danke Peter, dass du dir immer Zeit genommen hast und für deine blöden Kommentare, die dann doch oft hilfreich waren.

Danke euch beiden für die Freundschaft, dass ihr mich auf die ganzen Reisen mitgenommen habt und auch an Christian, Alex, Julia und Marina, dass ihr mich beim Sammeln begleitet habt. Es war die beste Zeit meines Lebens.

Danke Marianne, Barbara und Daniela für die Betreuung im Labor und die freundliche Aufnahme in die Arbeitsgruppe. 


\section{Inhaltsverzeichnis}

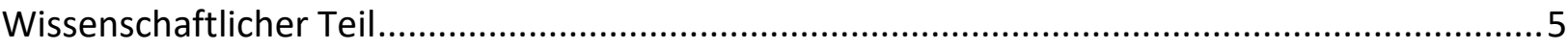

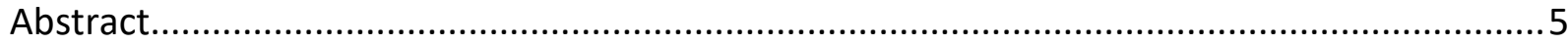

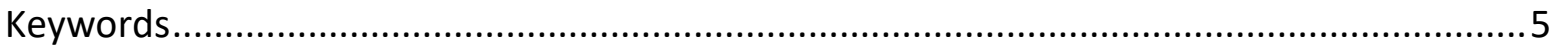

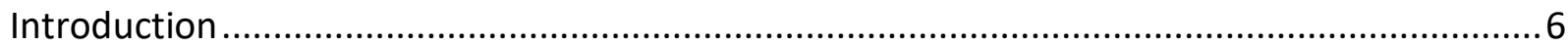

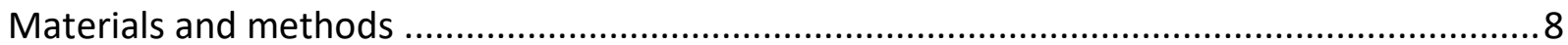

Plant material.

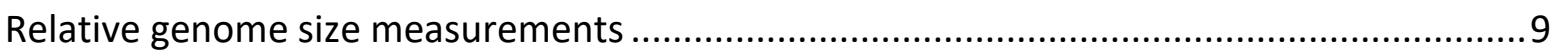

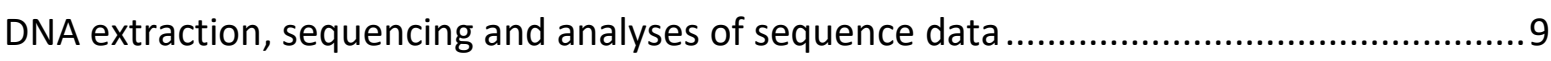

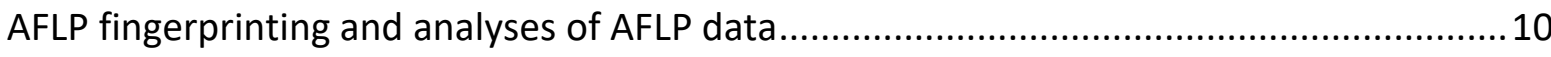

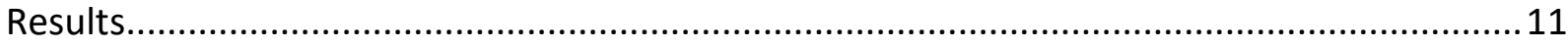

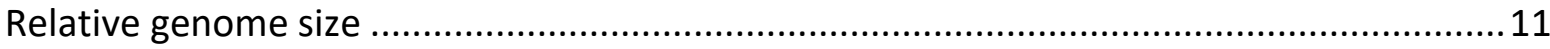

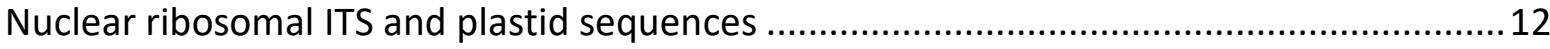

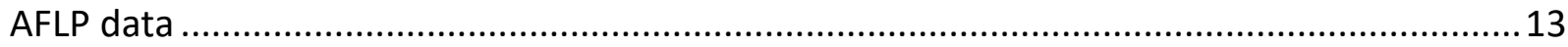

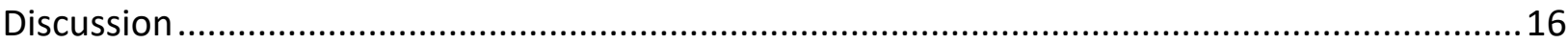

Vicariance in Pleistocene refugia in the Adriatic-Ionian and the Aegean-Pontic regions ..... 16

Strong genetic differentiation within the Aegean-Pontic area .........................................17

Amphi-Adriatic divergence and phylogeographic structure in the western Balkan. ............18

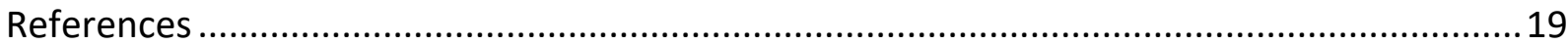

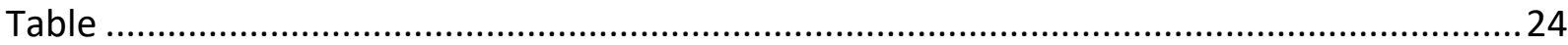

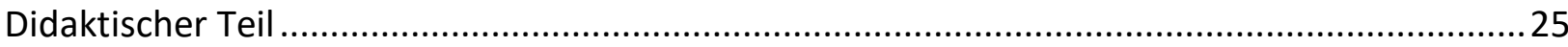

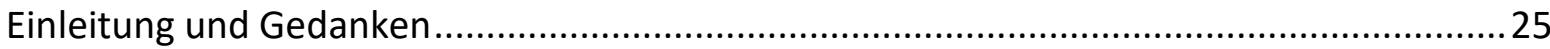

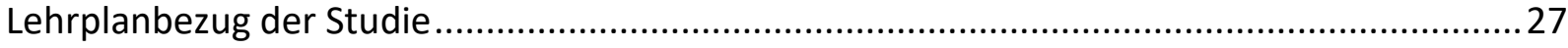

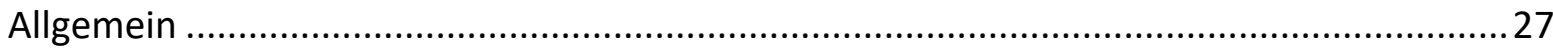

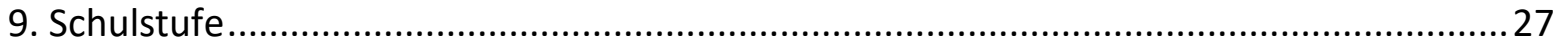

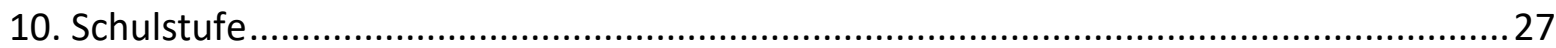




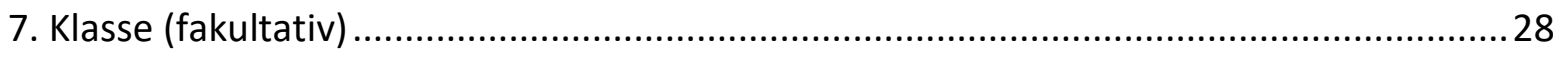

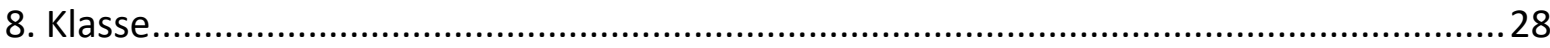

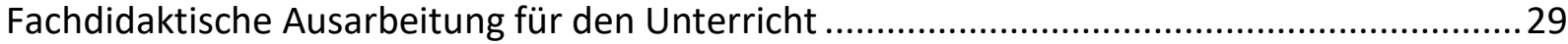

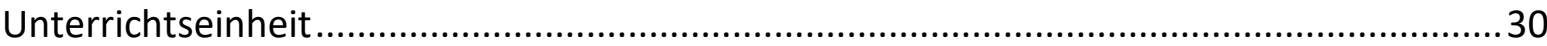

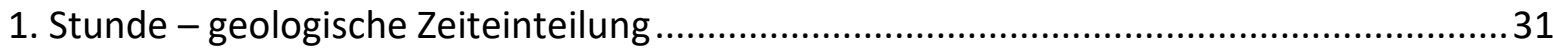

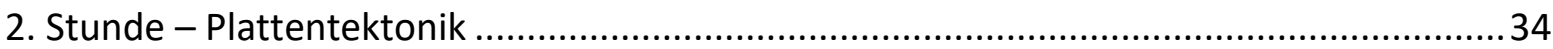

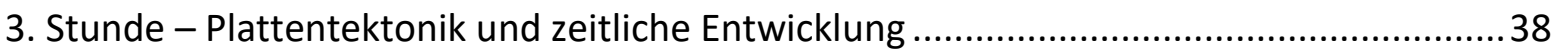

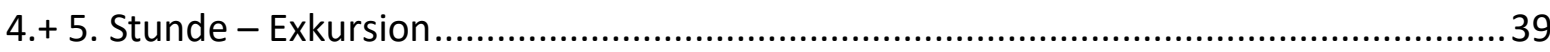

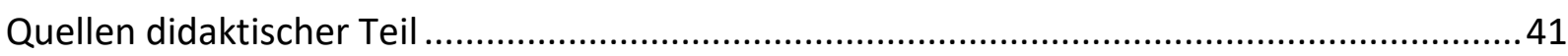

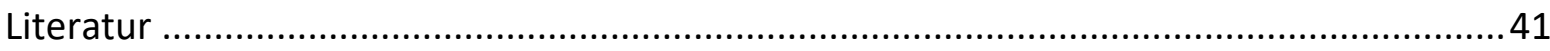

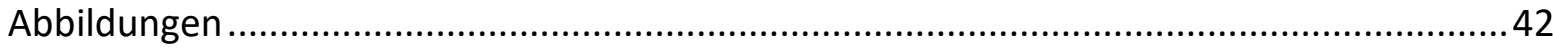

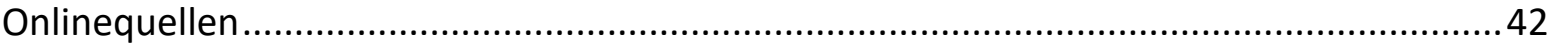




\section{Wissenschaftlicher Teil}

Dieser Teil wurde als wissenschaftlicher Artikel bei »Perspectives in Plant Ecology, Evolution and Systematics« (PEES) eingereicht.

\section{Abstract}

The Eastern Mediterranean is considered both a reservoir for plant evolution and a cradle for lineage diversification, but most plant groups from this area remain unstudied. To explore phylogeographic patterns within Eastern Mediterranean Euphorbia myrsinites, covering the area from the Apennines to Central Anatolia, we sequenced nuclear ribosomal ITS and the plastid trnT-trnF region and generated amplified fragment length polymorphism (AFLP) fingerprints, along with relative genome size (RGS) data. Our data reveal a complex evolutionary history of $E$. myrsinites since its origin at the Pliocene/Pleistocene boundary, resulting in a genetic structure which was shaped by fundamentally different processes acting at different time levels. Despite their weak glaciation in the Pleistocene, the high mountain ranges of the western and southern Balkan Peninsula triggered the initial divergence within this species due to vicariance in the Adriatic-Ionian and the Aegean-Pontic Pleistocene refugia. Subsequent range expansions led to the intriguing situation that both clusters nowadays occur in close spatial proximity. In addition, stronger genetic differentiation in the Aegean-Pontic area probably reflects less severe impacts of glaciations and higher environmental stability throughout the Pleistocene in this area, as compared to the Amphi-Adriatic region. The colonization of the Apennine Peninsula from the Balkan Peninsula took place later in the species' evolutionary history, probably over land bridges connecting both peninsulas in the Pleistocene. On the western Balkan Peninsula, the main phylogeographic split is situated along the Neretva river valley. To the north of this valley we detected no population structure whereas strong genetic differentiation in the southerly adjacent areas confirms the "refugiawithin-refugia" hypothesis.

\section{Keywords}

Aegean region, Amphi-Adriatic distribution, AFLP, Balkan Peninsula, genome size, phylogenetic analyses. 


\section{Introduction}

The Eastern Mediterranean is considered both a reservoir for plant evolution and a cradle for lineage diversification (Mansion et al., 2009; Barres et al., 2013) and appears to be more diverse than the Western Mediterranean, despite its younger age (Nieto Feliner, 2014). This area with complex climatic and geologic history provides an ideal setting for studying evolution and biogeography (Ståhls et al., 2016) and many groups, including plants, remain unstudied (Poulakis et al., 2015). Its present configuration is the result of the collision of the Arabian plate with Eurasia in the middle Miocene, which closed the connection between the Tethys Sea and the Indian Ocean (Steininger and Rögl, 1984; Krijgsman, 2002). Further, it caused the uplifting of the Anatolian highlands, the emergence of the Aegean Sea (Mai, 1995) and the formation of the Mid-Aegean Trench, which is considered an important biogeographical barrier between the Anatolian and Balkan Peninsulas (Ståhls et al., 2016). Another important biogeographic barrier in the Eastern Mediterranean is the Adriatic Sea, which separates the Balkan from the Apennine Peninsula. Whereas the geological history of the latter during the Tertiary and the early Quaternary was mostly dominated by eustatic sea level changes, the genesis of the Balkan Peninsula was much more complex and marked by the unfolding and uplifting of the Balkan Mountains and the Hellenids in the Tertiary (Mai, 1995; Muelenkamp et al., 2003).

Important geologic events that strongly influenced the fluctuations of the sea level in the Eastern Mediterranean and triggered migrations of biota were the Messinian Salinity Crisis ca. 6.0-5.3 Ma (Steininger and Rögl, 1984; Duggen et al., 2003) and the Pleistocene glaciations (Mai, 1995; Poulakakis et al., 2015). During the Last Glacial Maximum, the level of the Mediterranean Sea was ca. $120 \mathrm{~m}$ lower compared to the present (Shackleton, 1987). Pleistocene sea level fluctuations led to repeated openings and closings of land bridges in the Aegean region (Mai, 1995; Poulakakis et al., 2015) and to north-south shifts of the northern shore of the Adriatic Sea (Correggiari et al., 1996). Many plant species spread from the Balkan Peninsula to the Italian Peninsula during that period (Frajman and Schönswetter, 2017).

The sea level fluctuations triggered also changes in overall climate. For instance, the lowering of the sea level and the desiccation of large areas during the Pleistocene glaciations led to a more arid climate (Rapp, 2012), for example in the northern Adriatic region (Horvat et al., 1974). Changes in the amount of precipitation along with temperature oscillations strongly influenced distribution patterns and migration of biota. The mountains of the Balkan Peninsula were much less affected by glaciations as compared to other ranges of the Southern European 
mountain system (Nieto Feliner, 2014); still, the highest mountain ranges were glaciated (Turrill, 1929; Horvat et al., 1974) and presented a biogeographic barrier, especially for warmadapted species. The complex topography of the southern Balkan Peninsula is thus likely responsible for the stronger genetic differentiation observed in many plant species compared to northerly adjacent areas (e.g., Kutnjak et al., 2014; Surina et al., 2014; Caković et al., 2015; Đurović et al., 2017).

Euphorbia L. (Euphorbiaceae) is with more than 2150 species one of the largest genera of flowering plants. Most Eurasian species belong to Euphorbia subgen. Esula Pers., which is sister to the three other subgenera (Horn et al., 2012). It comprises 480 species and represents the most significant radiation of the genus in temperate areas of the Old World, with currently 21 sections recognized (Riina et al., 2013). One of the smaller sections is E. sect. Myrsiniteae (Boiss.) Lojac with 14, mostly perennial taxa distributed from Iberia and Morocco in the west to the Caucasus and the Iranian highlands in the East. The onset of the diversification of the perennial members was dated to the transition between Pliocene and Pleistocene, $2.7 \mathrm{Ma}$ (million years ago; Horn et al., 2014). The species with the largest distribution within this section is E. myrsinites L., occurring from Italy over the Balkan Peninsula and Asia Minor to the Caucasus (Pahlevani et al., 2011). Populations from northern Iran currently treated as $E$. myrsinites (Pahlevani et al., 2011) are genetically divergent and belong to another species (Pahlevani and Frajman, unpublished). In addition, the populations from the Caucasus and the Pontic area in Asia Minor have sometimes been treated as E. pontica (Prokhanov, 1949), but deemed conspecific with E. myrsinites by Pahlevani et al. (2011). Euphorbia myrsinites is a diploid ( $2 n=20$; Rice et al., 2015) glabrous, glaucous, decumbent to ascending perennial herb with several stems arising from a woody stock. Its semi-succulent cauline leaves are variable in shape, with palmate venation characteristic for this section. The cyathial glands are crescentshaped, horned, with slightly dilated tips (Radcliffe-Smith and Tutin, 1968). The species grows on rocky and stony slopes, pine woods and mountain pastures from sea level up to $2200 \mathrm{~m}$ (Radcliffe-Smith, 1982).

Most available phylogeographic studies focusing on the Eastern Mediterranean have explored the genetic structure of species with relatively narrow distributions limited to specific areas of the Balkan Peninsula (e.g., Kutnjak et al., 2014; Caković et al., 2015) or the Aegean Islands (e.g., Bittkau and Comes, 2005; Crowl et al., 2015), or have dealt with interspecific relationships of more widely distributed species groups (e.g., Frajman and Oxelman 2007, Đurović et al., 2017; Frajman and Schönswetter, 2017; Cresti et al., in press). In contrast, we 
here explore phylogeographic patterns within widely distributed Euphorbia myrsinites, covering the area from the Apennines to Central Anatolia. To this end, we generated sequences of nuclear ribosomal ITS and the plastid trnT-trnF region as well as amplified fragment length polymorphisms (AFLP), along with relative genome size (RGS) data. Specifically, we investigated (1) which biogeographic barrier (ocean vs. mountain ranges) had the strongest influence on the genetic structure, and (2) whether the genetic differentiation within this species, particularly within its amphi-Adriatic distribution area and on the Balkan Peninsula, follows the general trends uncovered by previous studies.

\section{Materials and methods}

\section{Plant material}

We sampled 59 populations of E. myrsinites from Italy to Central Anatolia. Leaf material of one to five individuals per population was collected and immediately stored in silica gel for phylogenetic and flow cytometric analyses. Relative genome size was measured for 57 populations, AFLP fingerprinting was performed for 51 populations and ITS and trnT-trnF were sequenced for one individual from 49 and 47 populations, respectively (Table A. 1, Fig. 1). Voucher data are presented in Table A. 1.

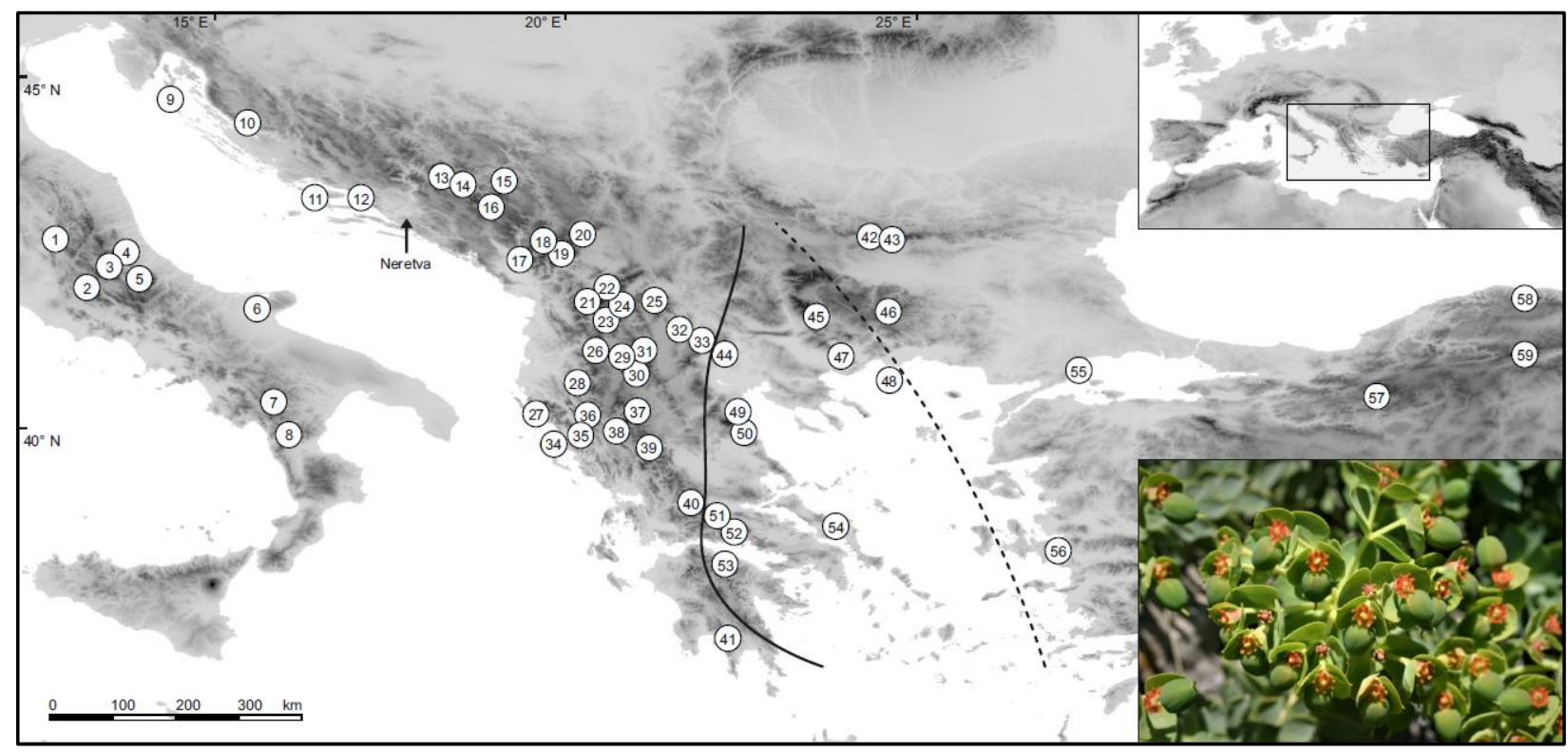

Figure 1: Sampled populations of Euphorbia myrsinites (shown in the lower right corner). The inset in the upper right corner shows the position of the area in Europe. The solid line indicates the position of the main genetic break revealed by the AFLP data and the broken line the position of the main break within the Aegean Group. Population numbers correspond to Table 1. 


\section{Relative genome size measurements}

Flow cytometry (FCM) of 4',6-diamidino-2-phenylindole (DAPI)-stained nuclei was used to estimate the RGS following the procedure described by Suda and Trávníček (2006). The RGS was estimated using Bellis perennis ( $2 \mathrm{C}=3.38$ pg; Schönswetter et al., 2007) as a reference standard. One to five individuals per population (Table A. 1) were analysed, mostly pooling two individuals, after an initial trial had been performed. A CyFlow space flow cytometer (Symex Partec, GmbH, Görlitz, Germany) was used to record the relative fluorescence of 3000 nuclei and FloMax software (Sysmex Partec) was used to evaluate histograms and to calculate coefficients of variation (CVs) of the standard and sample peaks. The RGS was calculated as the ratio between the values of the mean relative fluorescence of the sample and the standard. The package 'ggplot2' for R 3.3.2 (R Core Team, 2017) was used to produce a scatter plot. A OneWay-ANOVA was used to investigate if there are significant differences in RGS between the Adriatic and the Aegean Group inferred by the AFLP data.

\section{DNA extraction, sequencing and analyses of sequence data}

Extraction of total genomic DNA and sequencing were performed as described by Frajman and Schönswetter (2011), with the exception that the sequencing was carried out at Eurofins Genomics (Ebersberg, Germany). Contigs were assembled, edited and sequences aligned using Geneious Pro 5.5.9 (Kearse et al., 2012). Base polymorphisms were coded using NC-IUPAC ambiguity codes. GenBank numbers of ingroup sequences are given in Table A. 1. As preliminary analyses of sequence data using Maximum parsimony and Bayesian analyses resulted in an unresolved polytomy, we produced a NeighbourNet of ITS sequences using SplitsTree4 12.3 (Huson and Bryant, 2006). The plastid trnT-trnF sequences were analysed using statistical parsimony as implemented in TCS (Clement et al. 2000) with the connection limit set to 95. Gaps were treated as fifth character state and one indel longer than 1 base pair (bp) was reduced to a single bp column prior to the analysis, allowing this structural mutation to be counted as single base pair mutation only. Before TCS was performed, one $18 \mathrm{bp}$ long insertion in E. myrsinites pop. 34 was reduced to $1 \mathrm{bp}$ and an indel position in a poly-T region (alignment positions 763-772) was deleted. 


\section{AFLP fingerprinting and analyses of AFLP data}

One to five individuals per population (mean 3 individuals) from 51 populations, totalling 157 individuals, were used for further analyses (Table A. 1). The AFLP procedure followed Vos et al. (1995) with modifications described by Frajman et al. (2016). An initial screening of selective primers using 12 primer combinations with three nucleotides was performed. The three final primer combinations for the selective PCR (fluorescent dye in brackets) were EcoRI (FAM)ACA/Msel-CAC, EcoRI (VIC)-AGG/Msel-CTG, EcoRI (NED)-ACC/Msel-CAG. The selective PCR products were purified as described in Schönswetter et al. (2009). Then $1 \mu \mathrm{l}$ of the elution product was mixed with $10 \mu \mathrm{l}$ formamide and $0.13 \mu \mathrm{l}$ GeneScan 500 ROX (Applied Biosystems, Foster City, CA, USA) and ran on an ABI 3130 automated capillary sequencer. Two blanks (DNA replaced by water) were included to test for contamination, and 29 samples were used as replicates between the two PCR batches to test the reproducibility of the technique.

Electropherograms were analysed with Peak Scanner v1.0 (Applied Biosystems) in the size range of 100 to $500 \mathrm{bp}$ using the default peak detection method. Automated binning and scoring of the AFLP fragments were performed using RawGeno 2.0-2 (Arrigo et al. 2009) for R 3.3.2 (R Core Team, 2017) with the following settings: scoring range: 100-500 bp, minimum intensity $=100$ relative fluorescens units (RFUs), minimum bin width $=1 \mathrm{bp}$ and maximum bin width $=1.5 \mathrm{bp}$. Fragments with a reproducibility lower than $85 \%$ based on sample-replicate comparisons were eliminated. The error rate (Bonin et al. 2004) was calculated as the ratio of mismatches (scoring 1 versus 0) over phenotypic comparisons in AFLP profiles of replicated individuals. Fragments with singular occurrences were eliminated.

A Neighbour-joining (NJ) analysis based on Nei-Li genetic distances (Nei and Li 1979) was conducted and bootstrapped (2000 pseudo-replicates) with TREECON v.1.3b (van de Peer and De Wachter 1997). The tree was mid-point-rooted. SplitsTree4 12.3 (Huson and Bryant, 2006) was used to produce a NeighbourNet based on uncorrected P-distances. To identify the genetic structure within E. myrsinites, the Bayesian multilocus assignment method implemented in BAPS 5.2 (Corander et al. 2003) was both applied for all individuals and for the Western Group (populations 1-41; see Results). BAPS was run with the maximal number of groups (K) set to 210, using individuals as clustering units and without using geographic priors. Each run was replicated 10 times. Additionally, non-hierarchical K-means clustering (Hartigan and Wong 1979) was performed for 121 individuals (Western Group) using a script of Arrigo et al. (2010) for R 3.3.2 (R Core Team, 2017). A total of 50,000 independent runs were performed (i.e. 
starting from random points) for each assumed value for $\mathrm{K}$ clusters ranging from 2 to 10 . To select the best number of groups, the strategy proposed by Evanno et al. (2005) was used. Genetic groups were then plotted on a map created in QGis 2.18 (QGIS Development Team, 2018).

\section{Results}

\section{Relative genome size}

The mean RGS ranged between 1.10 (populations 23 and 55) and 1.22 (population 41; Fig. 2), thus indicating no variation in ploidy level. The RGS of the Adriatic AFLP Group ranged between 1.10 (population 23) and 1.22 (population 41) and that of the Aegean AFLP Group between 1.10 (population 55) and 1.18 (populations 42 and 58); the ANOVA rejected significant differentiation in RGS between both groups $\left(F_{4,52}=0.91, p=0.47, \alpha=0.05\right)$.

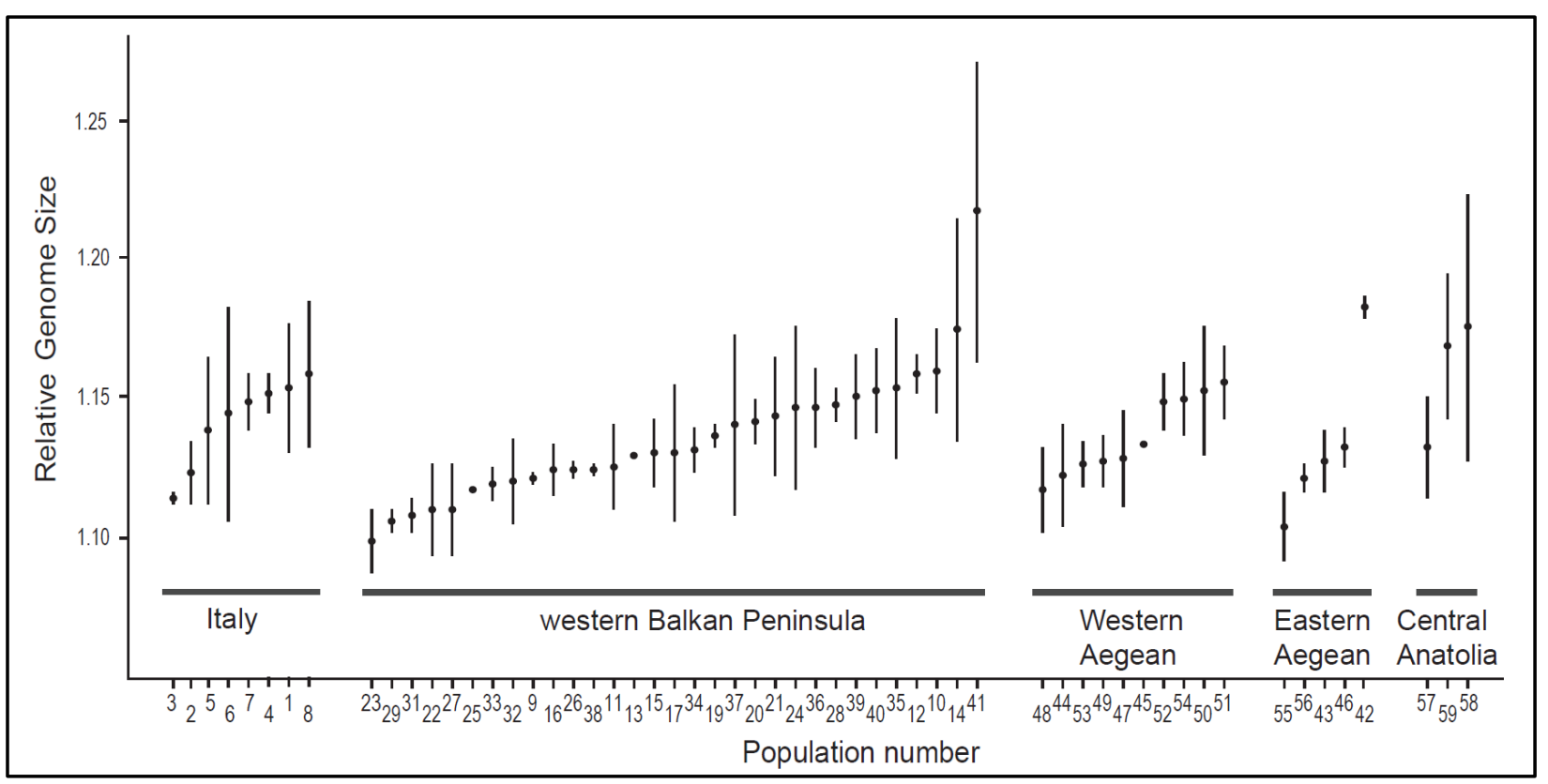

Figure 2: Relative genome size (RGS) variation in Euphorbia myrsinites. Population numbers correspond to Table 1 and Figure 1. Shown are population mean values (dot) and standard deviation (line). 
The NeighbourNet of ITS (Fig. 3A) sequences indicated a genetic split between the easternmost populations (42-59) from Bulgaria, eastern Greece and Turkey, and the remaining, western Balkan and Italian populations; furthermore, the northern Italian populations (6-8) were separated from the southern ones (2-5). With the exception of the Italian populations (1-8) and population 40 from Greece, which were genetically divergent, the other western Balkan populations were fairly uniform. In contrast, the eastern Balkan and Turkish populations were more strongly divergent.

Eleven different plastid haplotypes were found; 35 populations had the same, central haplotype in the TCS network (Fig. 3B). With exception of the two western Balkan populations 25 and 34, all other divergent haplotypes were found in the Bulgarian, eastern Greek and Turkish populations, which were genetically divergent.

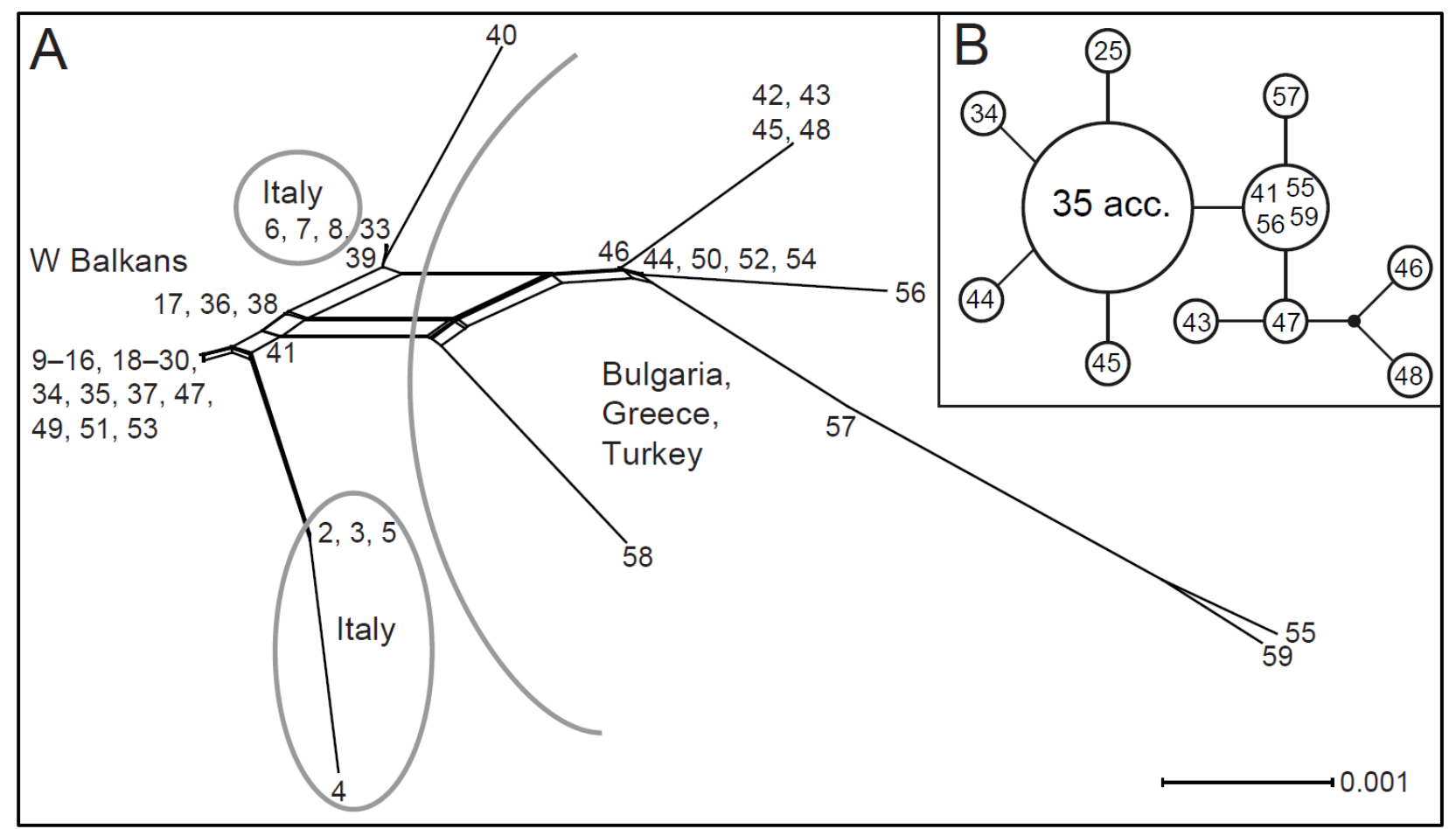

Figure 3: Phylogenetic relationships in Euphorbia myrsinites inferred by ITS and plastid trnT-trnF sequences, displayed as a NeighbourNet diagram (A) and a statistical parsimony network of haplotypes (B). Population identifiers correspond to Table 1 and Figure 1. The size of the circles in the haplotype network is relative to the square root of a haplotype's frequency. A not sampled haplotype is shown as a black dot. 


\section{AFLP data}

We scored 342 AFLP fragments ranging from 101 to $469 \mathrm{bp}$. The error rate amounted to $2.9 \%$. The NJ-tree revealed two major groups (Fig. 4), corresponding to the Aegean-Pontic Group including Bulgarian, eastern Greek and Turkish populations (populations 42-59; bootstrap support, BS, 100\%) and the Adriatic-Ionian Group including all other populations (1-41; BS 100\%; the boundary between the two groups is indicated in Fig. 1 by a solid line); for simplicity we refer to these groups as Aegean and Adriatic Group hereafter. The Aegean Group was further separated into two clusters (broken line in Fig. 1), the western Aegean (BS 100\%) and the eastern Aegean-Pontic (BS 100\%) cluster. The relationships within the Adriatic Group were largely unresolved. Only the Italian populations (BS 100\%) and the Greek population 40 (BS 77\%) were clearly divergent. In the same line, the NeighbourNet of the Adriatic Group revealed a clear split between the Italian and Balkan populations and within these population assemblages geographically close populations mostly clustered together (Fig. 5). The BAPS analysis (not shown) resulted in four groups, corresponding to (1) the Italian populations (1-8), (2) a coastal Adriatic group of populations from Croatia, Albania and Greece (9-12, 27, 28, 3439), (3) a Dinaric group of populations from Bosnia and Herzegovina, Montenegro, Albania and Northern Macedonia (13-24, 26), and (4) a southeastern group of populations from Northern Macedonia, the Pindos Mountains and the Peloponnesus in Greece (25, 29-33, 40, 41). The four groups were largely congruent with the clustering of populations in the NeighbourNet and K-means analyses. K-means clustering at $\mathrm{K}=2$ (Fig. $5 \mathrm{~A}$ ) revealed a main split between the Balkan and Italian populations; the populations 17, 20 and 21 from Montenegro and northern Albania were admixed. At $K=3$ to $K=5$ (Fig. 5 B, C, D) the Italian populations always belonged to the same genetic cluster, whereas the Balkan populations were divided into smaller groups. At $\mathrm{K}=3$ the Croatian populations 9 to 12 north of river Neretva were separated from the other Balkan populations, which were hierarchically divided into smaller groups of geographically close populations with increasing $K$ (shown for $K=4$ and $K=5$ in Fig. 5 C, D); position of river Neretva is indicated in Fig. 1. 


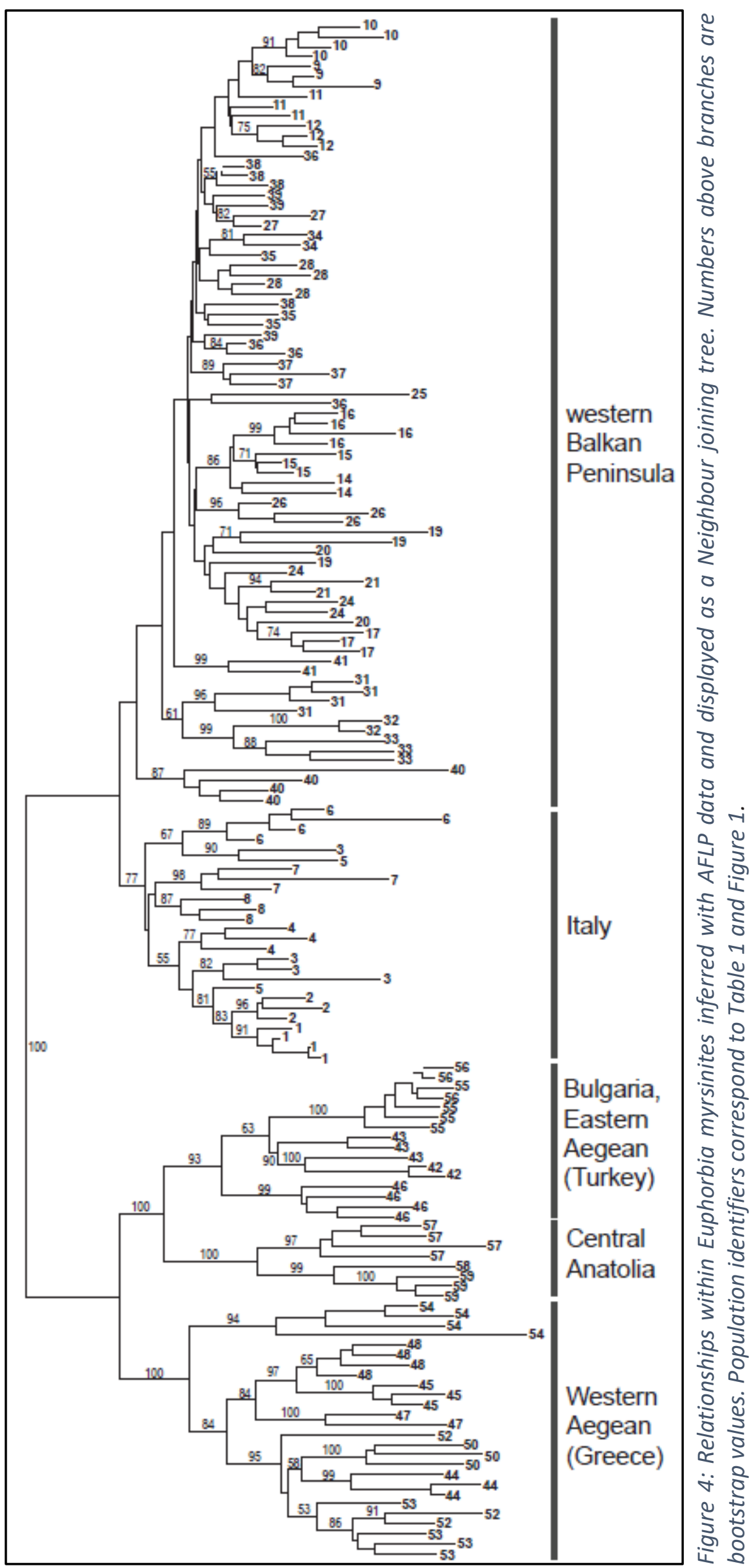




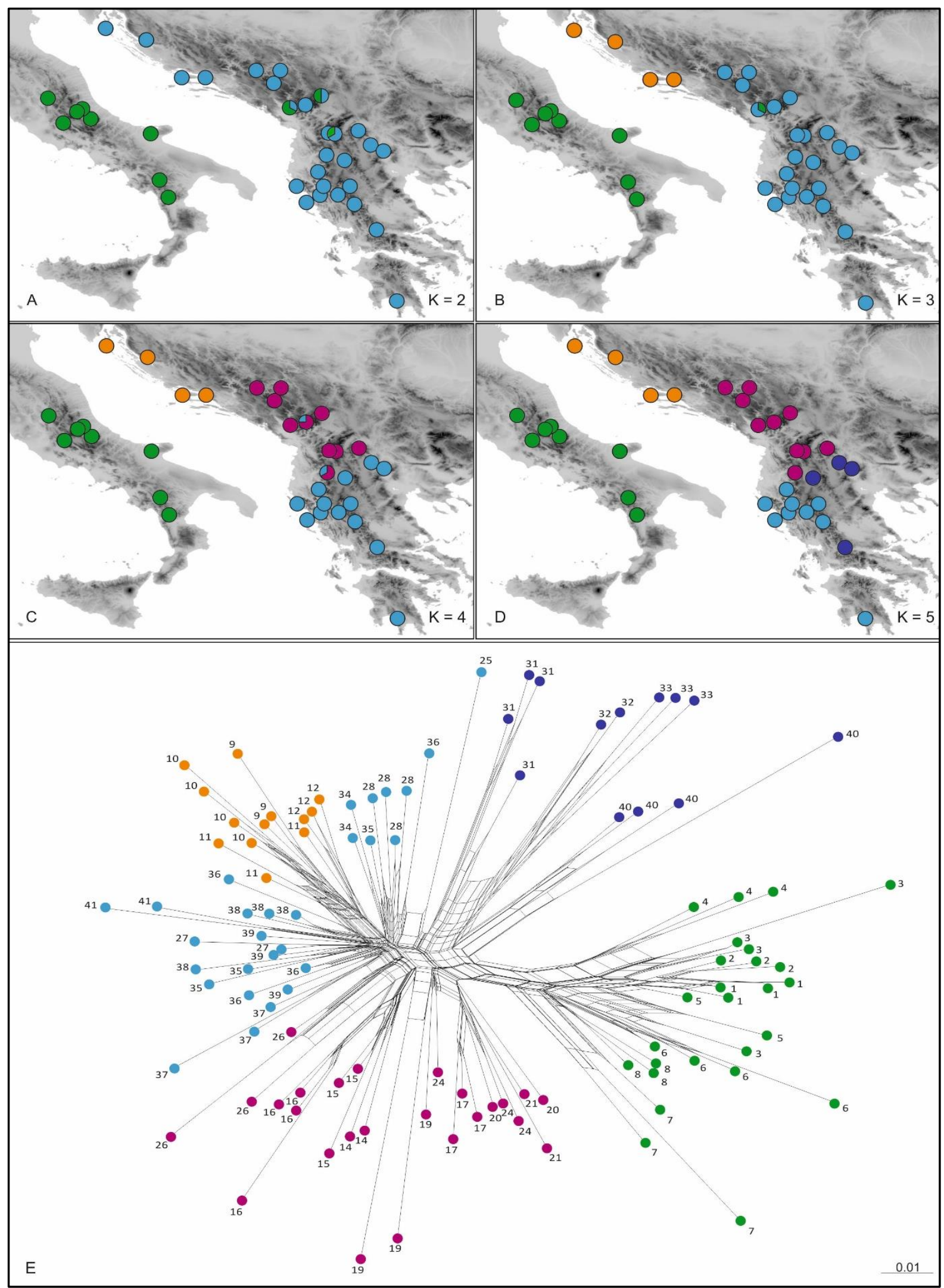

Figure 5: Relationships within the Adriatic Group of Euphorbia myrsinites inferred by AFLP fingerprinting. $A-D$ show the geographic distribution of the groups inferred by nonhierarchical $K$ means clustering at $K$, the number of groups, ranging between 2 and 5 . E NeighborNet based on uncorrected $P$ distances and indicated genetic groups as inferred by $K$-means clustering at $K=5$. Population identifiers correspond to Table 1 and Figure 1. 


\section{Discussion}

\section{Vicariance in Pleistocene refugia in the Adriatic-Ionian and the Aegean-Pontic regions}

Euphorbia sect. Myrsiniteae started to diversify in the late Pliocene around 2.7 Ma ago (Horn et al., 2014), implying that the species belonging to this section started their diversification and spread during the Pleistocene. The Pleistocene climatic oscillations were accompanied by fluctuations in the sea level and the formation of land bridges, which triggered range shifts of biota, and likely also shaped the phylogeographic structure in E. myrsinites. However, in contrast to the genetic evidence presented below, no large-scale structure is reflected in the RGS data (Fig. 2). Not only do all investigated populations have the same ploidy level and likely 20 chromosomes as confirmed by several chromosome counts for this species (Rice et al., 2015), but there was also no significant differentiation in RGS between the two major AFLP groups.

The main split in E. myrsinites as revealed by the AFLP data (Fig. 4) is - with exception of populations 47, 49, 51 and 53 - congruent with the main split seen in the ITS NeighbourNet (Fig. 3A) and divides the populations into the Adriatic and the Aegean Group. The geographic position of this split is surprising, as it runs through central Greece and south-eastern Northern Macedonia (solid line in Fig. 1), where the species has a more or less continuous distribution, whereas the biggest distribution gap and thus intuitively expected main genetic break is the Adriatic Sea (Fig. 1). The main genetic divergence in E. myrsinites was likely caused by isolation in two refugia during the Pleistocene glacials. The refugium for the Adriatic Group was probably positioned in the Adriatic-Ionian basin, and the one for the Aegean Group in the Aegean-Pontic area. Even if the mountains of the Balkan Peninsula were much less influenced by glaciations than, for instance, the Alps, the snow line was about $1000 \mathrm{~m}$ lower than today during the Last Glacial Maximum (Turrill, 1929; Horvat et al., 1974). The present altitudinal distribution of $E$. myrsinites ranges between coastal areas and $2000 \mathrm{~m}$ in the south of its range (Table A. 1); it was certainly much lower during colder periods. Then, the Dinaric Mountains and the adjacent Šara-Pindus mountain system probably presented a major barrier to gene flow, triggering genetic divergence by vicariance in two isolated areas.

After the glaciations $E$. myrsinites likely spread from both refugia through gradual range expansion (that is, diffusion; Lomolino et al., 2006), which was common for many species in the Mediterranean (Nieto Feliner, 2014), and genetically divergent lineages met again in geographic proximity in Greece. The two closest populations from both genetic lineages sampled by us 
(populations 33 and 44) are only $20 \mathrm{~km}$ apart, separated by Mount Kožuf/Tzena (2171 m) at the border between Greece and Northern Macedonia. Another such population pair separated by $50 \mathrm{~km}$ are populations 40 and 51 in the southern Pindos Mountains in Greece, albeit without obvious topographic barrier. Interestingly, population 40 is the most divergent of the Adriatic Group populations both in the AFLP Neighbour Joining tree (Fig. 4) and in the ITS NeighbourNet (Fig. $3 \mathrm{~A})$, probably suggesting introgression from geographically close populations of the Aegean Group.

\section{Strong genetic differentiation within the Aegean-Pontic area}

The genetic data show that the genetic differentiation among populations of the Aegean Group is much stronger than among populations of the Adriatic Group, as revealed by longer splits in the ITS NeighbourNet (Fig. 3A), several different plastid haplotypes (Fig. 3B) and several divergent lineages with high bootstrap support in the AFLP tree (Fig. 4). The main AFLP split within the Aegean Group (its geographic position is indicated by the broken line in Fig. 1) separates the western Aegean and the eastern Aegean-Pontic populations, suggesting divergence in two separate refugia in the Aegean area, possibly to the south-west and to the north-east or east of the Rhodope Mountains during a glacial later than the one conferring the main genetic split. Also, in this region both lineages nowadays occur in geographic proximity, but without indication of gene flow in our samples.

Stronger genetic divergence within the Aegean Group than within the Adriatic Group is likely caused by higher environmental stability during the Pleistocene compared to the more northerly situated Adriatic basin and the adjacent mountains (Nieto Feliner 2014). In accordance with the "refugia-within-refugia" hypothesis (Gómez \& Lunt, 2007) different genetic lineages within the Aegean Group were thus able to persist in different (micro)refugia, whereas in the Adriatic Group there was likely only a single refugium from where the species colonised its current distribution area (see below). Decreasing genetic diversity in east-to-west and southto-north direction in the Mediterranean Basin has been detected also in other plant groups, and was attributed to warmer and more humid conditions in the east vs. colder and dryer conditions in the west and increasing temperature from north to south during the Last Glacial Maximum (Wu et al., 2007; Surina et al., 2011; Conord et al., 2012; Nieto Feliner 2014). 
The Adriatic Group exhibits a lower genetic differentiation among populations as compared to the Aegean Group, with most populations sharing the same or similar ITS ribotypes and the same plastid haplotype (Fig. 3). The main genetic split revealed by the AFLP data (Fig. 4) separates the Italian populations - which have also divergent ITS sequences (Fig. 3A) - from the Balkan populations. Our data thus suggest a trans-Adriatic dispersal of E. myrsinites from the Balkan Peninsula to Italy, likely over land bridges that existed due to eustatic sea-level fluctuations and a southward dislocation of the northern Adriatic coast during cold stages of the Pleistocene (Shackleton, 1987; Correggiari et al., 1996). This pattern thus corroborates Pleistocene trans-Adriatic migration revealed in many other plant groups (reviewed by Frajman and Schönswetter, 2017). Admixed populations in Montenegro and northern Albania inferred by $\mathrm{K}$-means clustering at $\mathrm{K}=2$ and $\mathrm{K}=3$ (Fig. $5 \mathrm{~A}, \mathrm{~B}$ ) probably suggest that the Italian populations of E. myrsinites originate from this part of the Balkan Peninsula.

The genetic structure within the Balkan Peninsula is congruent with results of previous studies as the main split is positioned along the Neretva river valley (Fig. 1, 5B). The reasons for the presence of this phylogeographic break in different animal and plant taxa (e.g., Podnar et al., 2004; Frajman and Oxelman, 2007; Lakušić et al., 2013; Kutnjak et al., 2014; Caković et al., 2015) remain unclear. The genetic divergence was possibly triggered by divergent climatic conditions - that is, strong continentality in areas adjacent to the basin of the northern Adriatic Sea, which was dry during cold stages of the Pleistocene - rather than by a topographic barrier (Kutnjak et al., 2014).

Clustering of AFLP phenotypes of the Adriatic Group into more than two groups on the Balkan Peninsula ( $K=4, K=5$; Fig. 5C, D) revealed a hierarchical structure. The populations south of the Neretva river valley split into smaller, geographically coherent groups, which is congruent with patterns seen in other plant taxa (e.g., Kutnjak et al., 2014; Caković et al., 2015; Đurović et al., 2017) and further supports the role of the Balkan Peninsula as a sanctuary of genetic diversification (Lakušić et al., 2013; Surina et al., 2014). It remains unclear whether this weak genetic divergence originated in the late Pleistocene, e.g. due to isolation in different local refugia during the Last Glacial Maximum, or if it is younger and a result of differential stochastic genetic drift when the species expanded its range during the Holocene.

Altogether, the genetic structure uncovered in widespread eastern Mediterranean $E$. myrsinites was shaped by fundamentally different processes acting at different time levels. The 
oldest split, triggered by vicariance in two glacial refugia, resulted in two main genetic clusters. Subsequent range expansions led to the intriguing situation that both clusters nowadays occur in close spatial proximity. That is, the main genetic break runs through the virtually continuous distribution area, similarly as previously shown for Bupleurum stellatum in the Alps (Schönswetter et al., 2005). In contrast, the colonization of the Apennine Peninsula took place much later in the species' evolutionary history, rendering the Adriatic Sea, the intuitively most eminent barrier, a subordinate genetic break, as previously observed in various plant groups (e.g., Surina et al., 2014; Rešetnik et al., 2016; but see Frajman and Schönswetter, 2017).

\section{References}

Arrigo, N., Felber, F., Parisod, C., Buerki, S., Alvarez, N., David, J., Guadagnuolo, R., 2010. Origin and expansion of the allotetraploid Aegilops geniculata, a wild relative of wheat. New Phytol. 187, 1170-1180. https://doi.org/10.1111/j.1469-8137.2010.03328.x

Arrigo, N., Tuszynski, J.W., Ehrich, D., Gerdes, T., Alvarez, N., 2009. Evaluating the impact of scoring parameters on the structure of intra-specific genetic variation using RawGeno, an $\mathrm{R}$ package for automating AFLP scoring. BMC Bioinformatics 10. https://doi.org/10.1016/S19917902(10)60012-8

Barres, L., Sanmartin, I., Anderson, C.L., Susanna, A., Buerki, S., Galbany-Casals, M., Vilatersana, R., 2013. Reconstructing the evolution and biogeographic history of tribe Cardueae (Compositae). Am. J. Bot. 100, 867-882. https://doi.org/10.3732/ajb.1200058

Bittkau, C., Comes, H.P., 2005. Evolutionary processes in a continental island system: molecular phylogeography of the Aegean Nigella arvensis alliance (Ranunculaceae) inferred from chloroplast DNA. Mol. Ecol. 14, 4065-4083. https://doi.org/10.1111/j.1365-294X.2005.02725.X

Bonin, A., Bellemain, E., Eidesen, P.B., Pompanon, F., Brochmann, C., Taberlet, P., 2004. How to track and assess genotyping errors in population genetics studies. Mol. Ecol. 13, 3261-3273. https://doi.org/10.1111/j.1365-294X.2004.02346.x

Caković, D., Stešević, D., Schönswetter, P., Frajman, B., 2015. How many taxa? Spatiotemporal evolution and taxonomy of Amphoricarpos (Asteraceae, Carduoideae) on the Balkan Peninsula. Org. Divers. Evol. https://doi.org/10.1007/s13127-015-0218-6

Clement, M., Posada, D., Crandall, K.A., 2000. TCS: a computer program to estimate gene genealogies. Mol. Ecol. 9, 1657-1659. https://doi.org/10.1046/j.1365-294X.2000.01020.x

Conord, C., Gurevitch, J., Fady, B., 2012. Large-scale longitudinal gradients of genetic diversity: a meta-analysis across six phyla in the Mediterranean basin. Ecol. Evol. 2, 2595-2609. https://doi.org/10.1002/ece3.350

Corander, J., Waldmann, P., Sillanpää, M.J., 2003. Bayesian analysis of genetic differentiation between populations. Genetics 163, 367-374. https://doi.org/10.1093/bioinformatics/bth250 
Correggiari, A., Roveri, M., Trincardi, F., 1996. Late Pleistocene and Holocene evolution of the North Adriatic Sea. Quat. Ital. J. Quat. Sci. 9, 697-704. https://doi.org/10.1016/0025$\underline{3227(79) 90130-0}$

Cresti, L., Schönswetter, P., Peruzzi, L., Barfuss, M. H. J., Frajman, B., in press. Pleistocene survival in three Mediterranean refugia: origin and diversification of the Italian endemic Euphorbia gasparrinii from the E. verrucosa alliance (Euphorbiaceae).

Crowl, A.A., Visger, C.J., Mansion, G., Hand, R., Wu, H.H., Kamari, G., Phitos, D., Cellinese, N., 2015. Evolution and biogeography of the endemic Roucela complex (Campanulaceae: Campanula) in the Eastern Mediterranean. Ecol. Evol. 5, 5329-5343. https://doi.org/10.1002/ece3.1791

Duggen, S., Hoernle, K., van den Bogaard, P., Rüpke, L., Phipps Morgan, J., 2003. Deep roots of the Messinian salinity crisis. Nature 422, 602-606. https://doi.org/10.1038/nature01553

Đurović, S., Schönswetter, P., Niketić, M., Tomović, G., Frajman, B., 2017. Disentangling relationships among the members of the silene saxifraga alliance (Caryophyllaceae): Phylogenetic structure is geographically rather than taxonomically segregated. Taxon 66, 343364. https://doi.org/10.12705/662.4

Evanno, G., Regnaut, S., Goudet, J., 2005. Detecting the number of clusters of individuals using the software STRUCTURE: A simulation study. Mol. Ecol. 14, 2611-2620. https://doi.org/10.1111/j.1365-294X.2005.02553.x

Frajman, B., Graniszewska, M., Schönswetter, P., 2016. Evolutionary patterns and morphological diversification within the European members of the Euphorbia illirica (E. villosa) group: one or several species? Preslia 88, 369-390.

Frajman, B., Heidari, N., Oxelman, B., 2009. Phylogenetic relationships of Atocion and Viscaria (Sileneae, Caryophyllaceae) inferred from chloroplast, nuclear ribosomal, and low-copy gene DNA sequences. Taxon 58, 811-824.

Frajman, B., Oxelman, B., 2007. Reticulate phylogenetics and phytogeographical structure of Heliosperma (Sileneae, Caryophyllaceae) inferred from chloroplast and nuclear DNA sequences. Mol. Phylogenet. Evol. 43, 140-155. https://doi.org/10.1016/j.ympev.2006.11.003

Frajman, B., Rešetnik, I., Niketić, M., Ehrendorfer, F., Schönswetter, P., 2016. Patterns of rapid diversification in heteroploid Knautia sect. Trichera (Caprifoliaceae, Dipsacoideae), one of the most intricate taxa of the European flora. BMC Evol. Biol. 16, 1-20. https://doi.org/10.1186/s12862-016-0773-2

Frajman, B., Schneeweiss, G.M., 2009. A Campanulaceous fate: the Albanian steno endemic Asyneuma comosiforme in fact belongs to isophyllous Campanula. Am. Soc. Plant Taxon. 34, 595-601. https://doi.org/10.1600/036364409789271173

Frajman, B., Schönswetter, P., 2017. Amphi-Adriatic distributions in plants revisited: Pleistocene trans-Adriatic dispersal in the Euphorbia barrelieri group (Euphorbiaceae). Bot. J. Linn. Soc. 185, 240-252. https://doi.org/10.1093/botlinnean/box055

Frajman, B., Schönswetter, P., 2011. Giants and dwarfs: molecular phylogenies reveal multiple origins of annual spurges within Euphorbia subg. Esula. Mol. Phylogenet. Evol. 61, 413-424. https://doi.org/10.1016/j.ympev.2011.06.011 
Gomez, A., Lunt, D.H., 2007. Refugia within refugia: patterns of phylogeographic concordance in Iberian Peninsula., Phylogeography of Southern European Refugia. Springer, Berlin. https://doi.org/10.1016/j.cemconcomp.2005.07.003

Hartigan, J.A., Wong, M.A., 1979. Algorithm AS 136: A K-Means Clustering Algorithm. J. R. Stat. Soc. 28, 100-108.

Horn, J.W., van Ee, B.W., Morawetz, J.J., Riina, R., Steinmann, V.W., Berry, P.E., Wurdack, K.J., 2012. Phylogenetics and the evolution of major structural characters in the giant genus Euphorbia L. (Euphorbiaceae). Mol. Phylogenet. Evol. 63, 305-326. https://doi.org/10.1016/j.ympev.2011.12.022

Horn, J.W., Xi, Z., Riina, R., Peirson, J.A., Yang, Y., Dorsey, B.L., Berry, P.E., Davis, C.C., Wurdack, K.J., 2014. Evolutionary bursts in Euphorbia (Euphorbiaceae) are linked with photosynthetic pathway. Evolution (N. Y). 68, 3485-3504. https://doi.org/10.1111/evo.12534

Horvat, I., Glavač, V., Ellenberg, H., 1974. Vegetation Südosteuropas. Fischer, Stuttgart.

Huson, D.H., Bryant, D., 2006. Application of phylogenetic networks in evolutionary studies. Mol. Biol. Evol. 23, 254-267. https://doi.org/10.1093/molbev/msj030

Kearse, M., Moir, R., Wilson, A., Stones-Havas, S., Cheung, M., Sturrock, S., Buxton, S., Cooper, A., Markowitz, S., Duran, C., Thierer, T., Ashton, B., Meintjes, P., Drummond, A., 2012. Geneious Basic: An integrated and extendable desktop software platform for the organization and analysis of sequence data. Bioinformatics 28, 1647-1649. https://doi.org/10.1093/bioinformatics/bts199

Krijgsman, W., 2002. The Mediterranean: Mare Nostrum of Earth sciences. Earth Planet. Sci. Lett. 205, 1-12. https://doi.org/10.1016/S0012-821X(02)01008-7

Kutnjak, D., Kuttner, M., Niketić, M., Dullinger, S., Schönswetter, P., Frajman, B., 2014. Escaping to the summits: phylogeography and predicted range dynamics of Cerastium dinaricum, an endangered high mountain plant endemic to the western Balkan Peninsula. Mol. Phylogenet. Evol. 78, 365-374. https://doi.org/10.1016/j.ympev.2014.05.015

Lakušić, D., Liber, Z., Nikolić, T., Surina, B., Kovačić, S., Bogdanović, S., Stefanović, S., 2013. Molecular phylogeny of the Campanula pyramidalis species complex (Campanulaceae) inferred from chloroplast and nuclear non-coding sequences and its taxonomic implications. Taxon 62, 505-524. https://doi.org/10.12705/623.1

Lomolino, M. V., Riddle, B.R., Brown, J.H., 2006. Biogeography, 3rd ed. Sinauer, Sunderland.

Mai, D.H., 1995. Tertiäre Vegetationsgeschichte Europas. G. Fischer, Jena, Stuttgart, New York.

Mansion, G., Selvi, F., Guggisberg, A., Conti, E., Vegetale, B., 2009. Origin of Mediterranean insular endemics in the Boraginales: integrative evidence from molecular dating and ancestral area reconstruction. J. Biogeogr. 36, 1282-1296. https://doi.org/10.1111/j.13652699.2009.02082.x

Meulenkamp, J.E., Sissingh, W., 2003. Tertiary palaeogeography and tectonostratigraphic evolution of the Northern and Southern Peri-Tethys platforms and the intermediate domains of the African-Eurasian convergent plate boundary zone. Palaeogeogr. Palaeoclimatol. Palaeoecol. 196, 209-228. https://doi.org/10.1016/S0031-0182(03)00319-5 
Nei, M., Li, W.-H., 1979. Mathematical Model for Studying Genetic Variation in Terms of Restriction Endonucleases. PNAS 76, 5269-5273.

Nieto Feliner, G., 2014. Patterns and processes in plant phylogeography in the Mediterranean Basin. A review. Perspect. Plant Ecol. Evol. Syst. 16, 265-278. https://doi.org/10.1016/j.ppees.2014.07.002

Pahlevani, A., Geltman, D. V., Riina, R., 2011. Taxonomic Revision of Euphorbia subsect. Myrsiniteae in Iran. Ann. Bot. Fenn. 48, 483-493. https://doi.org/10.5735/085.048.0606

Podnar, M., Mayer, W., Tvrtkovic, N., 2004. Mitochondrial phylogeography of the Dalmatian wall lizard, Podarcis melisellensis (Lacertidae). Org. Divers. Evol. 4, 307-317. https://doi.org/10.1016/j.ode.2004.04.004

Poulakakis, N., Kapli, P., Lymberakis, P., Trichas, A., Vardinoyiannis, K., Sfenthourakis, S., Mylonas, M., 2015. A review of phylogeographic analyses of animal taxa from the Aegean and surrounding regions. J. Zool. Syst. Evol. Res. 53, 18-32. https://doi.org/10.1111/jzs.12071

Prokhanov, Y.I., 1949. Euphorbia L., in: Shishkin, B.K., Bobrov, E.G. (Eds.), Flora of the USSR. Akademy of Sciences USSR, Moscow, Leningrad, pp. 233-378.

GQIS Development Team, 2018. QGIS Geographic Information System. Open Source Geospatial Foundation Project. http://qgis.osgeo.org

Radcliff-Smith, A., 1982. Euphorbia L., in: Davis, P.H. (Ed.), Flora of Turkey. Edinburgh University Press, Edinburgh, pp. 571-630.

Radcliff-Smith, A., Tutin, T.G., 1968. Euphorbia L., in: Tutin, T.G., Heywood, V.H., Moore, D.M., Valentine, D.H., Walters, S.M., Webb, D.A. (Eds.), Flora Europaea. Cambridge University Press, Cambridge, pp. 213-226.

Rapp, D., 2012. Ice Ages and Interglacials. Springer, Berlin, Heidelberg.

R Core Team, 2017. R: A language and environment for statistical computing. R Foundation for Statistical Computing, Vienna, Austria. http://www.R-project.org/

Rešetnik, I., Frajman, B., Schönswetter, P., 2016. Heteroploid Knautia drymeia includes K. gussonei and cannot be separated into diagnosable subspecies. Am. J. Bot. 103, 1300-1313. https://doi.org/10.3732/ajb.1500506

Rice, A., Glick, L., Abadi, S., Einhorn, M., Kopelman, N.M., Salman-Minkov, A., Mayzel, J., Chay, O., Mayrose, I., 2015. The Chromosome Counts Database (CCDB) - a community resource of plant chromosome numbers. New Phytol. 206, 19-26. https://doi.org/10.1111/nph.13191

Riina, R., Peirson, J.A., Geltman, D. V., Molero, J., Frajman, B., Pahlevani, A., Barres, L., Morawetz, J.J., Salmaki, Y., Zarre, S., Kryukov, A., Bruyns, P. V., Berry, P.E., 2013. A worldwide molecular phylogeny and classification of the leafy spurges, Euphorbia subgenus Esula (Euphorbiaceae). Taxon 62, 316-342. https://doi.org/10.12705/622.3

Schönswetter, P., Solstad, H., García, P.E., Elven, R., 2009. A combined molecular and morphological approach to the taxonomically intricate European mountain plant Papaver 
alpinum s.l. (Papaveraceae) - Taxa or informal phylogeographical groups? Taxon 58, 13261343. https://doi.org/10.1002/tax.584020

Schönswetter, P., Suda, J., Popp, M., Weiss-Schneeweiss, H., Brochmann, C., 2007. Circumpolar phylogeography of Juncus biglumis (Juncaceae) inferred from AFLP fingerprints, cpDNA sequences, nuclear DNA content and chromosome numbers. Mol. Phylogenet. Evol. 42, 92-103. https://doi.org/10.1016/j.ympev.2006.06.016

Schönswetter, P., Tribsch, A., 2005. Vicariance and dispersal in the alpine perennial Bupleurum stellatum L. (Apiaceae). Taxon 54, 725-732. https://doi.org/10.2307/25065429

Shackleton, N.J., 1987. Oxygen isotopes, ice volume and sea level. Quat. Sci. Rev. 6, 183-190. https://doi.org/10.1093/nq/s2-VIII.201.373e

Ståhls, G., Vujić, A., Petanidou, T., Cardoso, P., Radenković, S., Ačanski, J., Pérez Bañón, C., Rojo, S., 2016. Phylogeographic patterns of Merodon hoverflies in the Eastern Mediterranean region: Revealing connections and barriers. Ecol. Evol. 6, 2226-2245. https://doi.org/10.1002/ece3.2021

Steininger, F.F., Rögl, F., 1984. Paleogeography and palinspastic reconstruction of the Neogene of the Mediterranean and Paratethys, in: Dixon, J.E., Robertson, A.H.F. (Eds.), The Geological Evolution of the Eastern Mediterranean. The Geological Society, London, pp. 659-669.

Suda, J. and Trávníćek, P., 2006. Estimation of relative nuclear DNA content in dehydrated plant tissues by flow cytometry. In: Robinson, J.P., Darzynkiewicz, Z., Dobrucki, J., Hyun, W.C., Nolan, J.P., Orfao, A., Rabinovitch, P.S. (Eds.), Current protocols in cytometry. John Wiley \& Sons, Inc., Hoboken, NJ, USA.

Surina, B., Schneeweiss, G.M., Glasnovië, P., Schönswetter, P., 2014. Testing the efficiency of nested barriers to dispersal in the Mediterranean high mountain plant Edraianthus graminifolius (Campanulaceae). Mol. Ecol. 23, 2861-2875. https://doi.org/10.1111/mec.12779

Surina, B., Schönswetter, P., Schneeweiss, G.M., 2011. Quaternary range dynamics of ecologically divergent species (Edraianthus serpyllifolius and E. tenuifolius, Campanulaceae) within the Balkan refugium. J. Biogeogr. 38, 1381-1393. https://doi.org/10.1111/j.13652699.2011.02493.x

Turril, W.B., 1929. The plantlife of the Balkan peninsula. A Phytogeographical Study. Clarendon Press, Oxford.

Van de Peer, Y., De Wachter, R., 1997. Construction of evolutionary distance trees with TREECON for Windows: accounting for variation in nucleotide substitution rate among sites. Bioinformatics 13, 227-230. https://doi.org/10.1093/bioinformatics/13.3.227

Vos, P., Hogers, R., Bleeker, M., Reijans, M., Lee, T. Van De, Hornes, M., Friters, A., Pot, J., Paleman, J., Kuiper, M., Zabeau, M., 1995. AFLP: A new technique for DNA fingerprinting. Nucleic Acids Res. 23, 4407-4414. https://doi.org/10.1093/nar/23.21.4407

Wu, H., Guiot, J., Brewer, S., Guo, Z., 2007. Climatic changes in Eurasia and Africa at the last glacial maximum and mid-Holocene: reconstruction from pollen data using inverse vegetation modelling 211-229. https://doi.org/10.1007/s00382-007-0231-3 
Table 1: Studied populations of Euphorbia myrsinites. In the columns 10 to 16 is indicated, in which part of the study each population was included. IDs correspond to population numbers in Table

\begin{tabular}{|c|c|c|c|c|c|c|c|c|c|c|c|}
\hline ID & Country & Latitude & \begin{tabular}{|l|} 
Longitude \\
\end{tabular} & Collection Nr. & AFLP & n Aflp & RGS (mean) & RGS (SD) & n RGS & Trnt - Trnf & ITS \\
\hline 1 & Italy & 42.701667 & 12.770278 & 14360 & + & 4 & 1.153 & 0.023 & 5 & + & - \\
\hline 2 & Italy & 42.007778 & 13.193333 & 14370 & + & 3 & 1.123 & 0.011 & 5 & + & + \\
\hline 3 & Italy & 42.315278 & 13.558333 & 14350 & + & 4 & 1.114 & 0.002 & 5 & + & + \\
\hline 4 & Italy & 42.402778 & 13.708889 & 13217 & + & 3 & 1.151 & 0.007 & 5 & + & + \\
\hline 5 & Italy & 42.116389 & 13.936389 & 13187 & + & 2 & 1.138 & 0.026 & 5 & - & + \\
\hline 6 & Italy & 41.6975 & 15.605 & 14366 & + & 4 & 1.144 & 0.038 & 5 & + & + \\
\hline 7 & Italy & 40.377778 & 15.841667 & 13174 & + & 3 & 1.148 & 0.01 & 5 & + & + \\
\hline 8 & Italy & 39.893611 & 16.078889 & 13156 & + & 3 & 1.158 & 0.026 & 5 & + & + \\
\hline 9 & Croatia & 44.675 & 14.361944 & 12478 & + & 3 & 1.121 & 0.002 & 5 & + & + \\
\hline 10 & Croatia & 44.35 & 15.485278 & 13097 & + & 5 & 1.159 & 0.015 & 5 & + & + \\
\hline 11 & Croatia & 43.279722 & 16.453056 & 12379 & + & 3 & 1.125 & 0.015 & 5 & + & + \\
\hline 12 & Croatia & 43.287778 & 17.100556 & 12383 & + & 3 & 1.158 & 0.007 & 5 & + & + \\
\hline 13 & Bosnia i Herzegovina & 43.562222 & 18.435 & 12040 & - & - & 1.129 & & 1 & + & + \\
\hline 14 & Bosnia i Herzegovina & 43.493333 & 18.492222 & 12634 & + & 2 & 1.174 & 0.04 & 5 & + & + \\
\hline 15 & Montenegro & 43.493333 & 19.156111 & 12910 & + & 3 & 1.13 & 0.012 & 5 & + & + \\
\hline 16 & Montenegro & 43.129444 & 18.986389 & 13831 & + & 4 & 1.124 & 0.009 & 5 & + & + \\
\hline 17 & Albania & 42.433056 & 19.417778 & 13001 & + & 3 & 1.13 & 0.024 & 5 & + & + \\
\hline 18 & Montenegro & 42.519444 & 19.79 & 13868 & - & - & & & & + & + \\
\hline 19 & Montenegro & 42.514444 & \begin{tabular}{|l|}
19.837778 \\
\end{tabular} & 13783 & + & 4 & 1.136 & 0.004 & 5 & + & + \\
\hline 20 & Kosovo & 42.768056 & 20.280556 & 13793 & + & 2 & 1.141 & 0.008 & 5 & + & + \\
\hline 21 & Albania & 41.714722 & 20.484722 & 14186 & + & 2 & 1.143 & 0.021 & 5 & - & + \\
\hline 22 & N. Macedonia & 41.791944 & 20.593333 & 13870 & - & - & 1.11 & 0.016 & 5 & + & + \\
\hline 23 & N. Macedonia & 41.715833 & 20.613889 & 14330 & - & - & 1.099 & 0.011 & 3 & - & - \\
\hline 24 & N. Macedonia & 41.684722 & 20.656667 & 13866 & + & 2 & 1.146 & 0.029 & 5 & + & + \\
\hline 25 & N. Macedonia & 41.785 & 21.297778 & 13916 & + & 1 & 1.117 & & 1 & + & + \\
\hline 26 & Albania & 41.084167 & 20.432222 & 13819 & + & 3 & 1.124 & 0.003 & 5 & + & + \\
\hline 27 & Albania & \begin{tabular}{|l|}
40.199722 \\
\end{tabular} & \begin{tabular}{|l|}
19.601111 \\
\end{tabular} & 13871 & + & 2 & 1.11 & 0.016 & 5 & + & + \\
\hline 28 & Albania & 40.62 & 20.191944 & 13801 & + & 4 & 1.147 & 0.006 & 5 & + & + \\
\hline 29 & N. Macedonia & 40.966667 & 20.814167 & 14329 & - & - & 1.106 & 0.004 & 3 & - & - \\
\hline 30 & N. Macedonia & 40.955556 & 20.819444 & 13867 & - & - & & & & + & + \\
\hline 31 & N. Macedonia & 40.934167 & 20.927222 & 14328 & + & 4 & 1.108 & 0.006 & 5 & - & - \\
\hline 32 & N. Macedonia & 41.371667 & 21.645556 & 14327 & + & 2 & 1.12 & 0.015 & 5 & - & - \\
\hline 33 & N. Macedonia & 41.2075 & 21.997778 & 12578 & + & 3 & 1.119 & 0.006 & 5 & + & + \\
\hline 34 & Greece & 39.750556 & 19.870833 & 14172 & + & 2 & 1.131 & 0.008 & 5 & + & + \\
\hline 35 & Albania & 39.947778 & 20.2425 & 13865 & + & 3 & 1.153 & 0.025 & 5 & + & + \\
\hline 36 & Albania & 40.197778 & 20.339722 & 13864 & + & 5 & 1.146 & 0.014 & 5 & + & + \\
\hline 37 & Greece & 40.204167 & 21.069167 & 13816 & + & 3 & 1.14 & 0.032 & 5 & + & + \\
\hline 38 & Greece & 39.971111 & 20.745556 & 13811 & + & 4 & 1.124 & 0.002 & 5 & + & + \\
\hline 39 & Greece & 39.695556 & 21.193611 & 14189 & + & 3 & 1.15 & 0.015 & 5 & + & + \\
\hline 40 & Greece & 38.965278 & 21.801944 & 14188 & + & 4 & 1.152 & 0.015 & 5 & + & + \\
\hline 41 & Greece & 36.954444 & 22.363333 & 13858 & + & 2 & 1.217 & 0.055 & 5 & + & + \\
\hline 42 & Bulgaria & 42.704167 & 24.409722 & 11287 & + & 2 & 1.182 & 0.004 & 3 & - & + \\
\hline 43 & Bulgaria & 42.719722 & 24.632778 & 12579 & + & 3 & 1.127 & 0.011 & 5 & + & + \\
\hline 44 & Bulgaria & 41.1125 & 22.223889 & 13465 & + & 3 & 1.122 & 0.018 & 5 & + & + \\
\hline 45 & Bulgaria & 41.570278 & 23.6125 & 13464 & + & 3 & 1.133 & 0.001 & 5 & + & + \\
\hline 46 & Bulgaria & 41.6275 & 24.640556 & 13853 & + & 4 & 1.132 & 0.007 & 5 & + & + \\
\hline 47 & Greece & 41.006667 & 23.948889 & 14397 & + & 2 & 1.128 & 0.017 & 5 & + & - \\
\hline 48 & Greece & 40.672778 & 24.653889 & 13854 & + & 4 & 1.117 & 0.015 & 5 & + & + \\
\hline 49 & Greece & 40.108889 & 22.474722 & 14398 & - & - & 1.127 & 0.009 & 5 & - & - \\
\hline 50 & Greece & 40.028889 & 22.497778 & 13859 & + & 3 & 1.152 & 0.023 & 5 & + & + \\
\hline 51 & Greece & 38.642222 & 22.22 & 14187 & - & - & 1.155 & 0.013 & 5 & - & - \\
\hline 52 & Greece & 38.656111 & 22.258611 & 14185 & + & 3 & 1.148 & 0.01 & 5 & - & + \\
\hline 53 & Greece & 38.023611 & 22.232222 & 14331 & + & 4 & 1.126 & 0.008 & 5 & + & - \\
\hline 54 & Greece & 38.586944 & 23.885278 & 13860 & + & 4 & 1.149 & 0.013 & 5 & - & + \\
\hline 55 & Turkey & 40.793611 & 27.362222 & 14120 & + & 4 & 1.104 & 0.012 & 5 & + & + \\
\hline 56 & Turkey & 38.235 & 27.106944 & 14116 & + & 3 & 1.121 & 0.005 & 5 & + & + \\
\hline 57 & Turkey & 40.431389 & 31.59 & 14102 & + & 4 & 1.132 & 0.018 & 5 & + & + \\
\hline 58 & Turkey & 41.806667 & 33.718056 & 14105 & + & 1 & 1.175 & 0.048 & 5 & + & + \\
\hline 59 & Turkey & 41.032778 & 33.725556 & 14107 & + & 3 & 1.168 & 0.026 & 5 & + & + \\
\hline
\end{tabular}




\section{Didaktischer Teil}

\section{Einleitung und Gedanken}

Biogeography is the science that attempts to document and understand spatial patterns of biological diversity. (...) Modern biogeography includes studies of all patterns of geographic variation in nature - from genes to entire communities and ecosystems - elements of biological diversity that vary across geographic gradients, including those of area, isolation, latitude, depth, and elevation.

Today the field is (...) recognized as one of science's most insightful and important disciplines, whose conceptual foundations extend back to ancient times.

Lomolino et al., 2010

Seit dem 17. und 18. Jahrhundert sehen wir in unserer westlichen Gesellschaft die Natur mit anderen Augen. Die modernen Naturwissenschaften fingen an, sich zu etablieren. Naturforscher gab es freilich schon viel früher. Thales von Milet (624-546 v. Chr.) war der erste dokumentierte Philosoph, der nachweißlich versuchte, die Gesetze der Natur zu ergründen (Brecht, 2015). Die frühen Denker waren jedoch immer gebunden an ihre unmittelbare Umwelt. Spätestens ab dem 18. Jahrhundert hatte man aber die Möglichkeit, in größeren Dimensionen zu denken. Durch die einsetzende globale Schifffahrt und ein ausgeprägtes Interesse der Öffentlichkeit (Meid, 2012), konnten die Entdecker und Naturforscher jener Zeit ein neues, globales Verständnis für die Vielfalt in der Natur begründen. „Sie stellten fest, dass Organismen und biologische Gemeinschaften in sehr regelmäßiger Weise entlang geographischer Breite, Seehöhe, Isolation und vorhandenem Lebensraum variierten. Sie stellten weiter fest, dass verschiedene Regionen der Erde - auch solche mit ähnlichen Klimazonen und Umweltbedingungen - bewohnt waren von unterschiedlichen Zusammenstellungen von Arten." (Lomolino et al., 2010) Diese Erkenntnisse gipfelten schließlich in den Evolutionstheorien von Darwin und Russel Mitte des 19. Jahrhunderts (Avise, 2000; Lomolino et al., 2010), die unser Weltbild seitdem massiv prägen. Nach und nach wurde immer deutlicher, dass sich unsere Umwelt verändert, dass sich Arten weiterentwickeln, sich den gegebenen Umweltbedingungen anpassen oder ihren angestammten Lebensraum verlassen (vgl. Donoghue, 2008). 
Dieses Wissen, das von Generationen von Naturforschern Indiz für Indiz zusammengetragen wurde, und uns heute zur Verfügung steht, kann für Laien und insbesondere auch für Schülerinnen und Schüler (SuS), anhand von exemplarischen Studien, wie sie etwa in dieser Arbeit vorliegt, anschaulich gemacht werden. Der Begriff Evolution, zweifellos bedeutend, gerade für die Schule (vgl. Lehrplan Biologie, 2018) und doch nichtssagend für den Laien, wird erst durch anschauliche Beispiele greifbar. Erst dann gilt: „Nichts in der Biologie macht Sinn, es sei denn betrachtet im Licht der Evolution." (Dobzhansky, 1937)

In einer Zeit, in der Halbwahrheiten und Verschwörungstheorien drohen, eine nüchterne, faktenbasierte Weltsicht, wie sie die Naturwissenschaften bieten, abzulösen, wird es umso wichtiger, mit klaren, verständlichen, an den Alltagserfahrungen der Menschen anknüpfenden Beispielen, diese zu untermauern und dadurch letztlich eine jahrhundertelange Tradition der Naturforschung zu konservieren und fortzusetzen. Genau in diesem Punkt sehe ich die Aufgabe von Biologielehrern und Biologielehrerinnen (BuB): Es ist ihre Aufgabe, die Flamme in den Herzen der SuS zu entzünden, ihre Aufgabe, ein Interesse für die Natur und deren Erforschung zu wecken. Nicht das molekularbiologische Labor, sondern die freie Natur, Exkursionen und Feldforschung, lassen die Abenteurer und Glücksritter wiederauferstehen, die in jeder Eintrittsvorlesung als wichtigste Wegbereiter unserer Disziplin gehuldigt werden. Die Vorstellung, einmal selbst auf der Endeavour oder der Beagle die Welt zu bereisen, neue Länder zu entdecken, vielleicht sogar eine neue Art zu beschreiben, steht am Anfang einer biologischen Karriere. Labor- und Computerarbeit, die freilich auch ihren Reiz haben, kommen früh genug. Am Anfang dieser Reise steht die Neugier und die Offenheit für die Natur: „Was ist das für eine Pflanze? Warum wächst sie hier, aber nicht woanders? Woher kommt sie? Was ist mit der Pflanze daneben, die ähnliche Blüten hat, aber sonst ganz anders ausschaut?“

Biogeografische Fallstudien können SuS jeden Alterns dabei helfen, die Natur besser zu verstehen und ein Gefühl für ihre Umwelt zu bekommen. Botanische Studien sind besonders hervorzuheben, da sich Pflanzen - einmal abgesehen von großen Säugetieren, zu denen wir oft einen emotionalen Bezug haben - im Allgemeinen besser greifen lassen, als Tiere.

Die vorliegende Arbeit wird vielleicht für den Unterricht an österreichischen Schulen nicht so wichtig sein, da sie sich mit einer vor allem ostmediterran verbreiteten Art auseinandersetzt (vgl. Lehrplan Biologie, 2018: regionale Arten sind zu bevorzugen), vergleichbare Studien zum Alpenraum liegen jedoch zur Genüge vor (z. B. Schönswetter et al., 2005; Magauer et al., 2014). 


\section{Lehrplanbezug der Studie}

\section{Allgemein}

„Ziel des Fachs Biologie und Umweltkunde ist es, naturwissenschaftliche Phänomene erfahrbar zu machen, sowie Erkenntnisse biologischer Forschung gewinnen, verstehen und kommunizieren zu können, und sich mit deren Grenzen auseinandersetzen zu können“ (Lehrplan für Biologie, 2018). Die Biogeografie als Disziplin besticht dadurch, dass sie eine Vielzahl von anderen Naturwissenschaften streift und in sich vereint. Sie ist in erster Linie eine Kombination von Biologie und Geografie. Für ihre Ausübung ist es aber auch wichtig, ein Verständnis für Ökologie, Paläontologie, Geologie, Genetik, Botanik, Zoologie, Ethologie, usw. zu entwickeln. Das funktioniert natürlich auch in die andere Richtung, so gibt einem das Studium der Biogeografie Einblicke in all diese Themenfelder. Aufgrund der unmittelbaren Greifbarkeit der Inhalte vieler dieser Studien eignen sie sich hervorragend für die Schule.

„Biogeography is accessible to almost anyone with the curiosity and motivation to tackle some of the greatest mysteries of nature. Large research grants, modern laboratory facilities (...) are not required to do state-of-the-art biogeographic research. All that is required is a good idea (...). This means that even beginning students can do original research"

(Lomolino et al., 2010).

Im Weiteren versuche ich hervorzuheben, in welchen Schulstufen diese Arbeit, oder Teile davon, einen Beitrag zum Unterricht leisten kann.

\section{Schulstufe}

- Bau, Fortpflanzung und Lebensweise pflanzlicher Organismen.

Wie entwickeln sich Arten, die voneinander isoliert in verschiedensten Lebensräumen leben? Gibt es generelle evolutive Trends? Divergenz und Konvergenz sind wichtige Themen aus der Biogeografie für die Schule.

Auch Verbreitungsmechanismen von Pflanzen sind interessant im biogeografischen Sinn. Bau und Funktion von Diasporen spielen eine wichtige Rolle bei der Erschließung neuer Lebensräume.

\section{Schulstufe}

- Vernetzte Systeme: Ökologie, Ökonomie und Nachhaltigkeit, Ökosysteme, Umweltprobleme. 
Organismen verbreiten sich auf unterschiedlichste Art und Weise. Eine davon ist die Verschleppung durch den Menschen, sei es als Nützling oder als blinder Passagier. Für das Holozän gibt es eine Vielzahl an dokumentierten Ereignissen, wo eine Verbreitung durch den Menschen stattgefunden hat (z.B. Poulakakis et al., 2015). Gerade in jüngster Zeit, gibt es viele Fälle von Neobiota, die problematisch werden für ihr neues Umfeld. Für Tirol wären hier Ragweed (Ambrosia artemisifolia), Robinie (Robinia pseudoacacia) und das drüsige Springkraut (Impatiens glandulifera) als prominente Beispiele unter vielen zu nennen.

„Der Klimawandel“ oder besser gesagt ein Klimawandel ist natürlich immer eine massive Triebkraft für die Evolution und biogeografische Veränderung. Auch in dieser Studie wird das sehr deutlich. Erst die Veränderung des Klimas hin zu einem trockenen, winterfeuchten Klima, wie wir es heute im Mittelmeerraum kennen, konnte sich die Gattung Euphorbia so stark im mediterranen Raum diversifizieren und etablieren.

- Aufbau und Struktur der Erde, geodynamische Formungskräfte.

Geodynamische Formungskräfte haben natürlich einen massiven Einfluss auf die Biogeografie. Ähnlich wie das Klima, sind sie maßgeblich an der Verbreitung von Spezies beteiligt, sei es durch die Bildung von Landbrücken oder die Auffaltung ganzer Gebirge. Das geht aus dieser und vielen anderen Studien hervor. Ein Beispiel für die Behandlung in der Schule werde ich weiter unten noch vorstellen.

\section{Klasse (fakultativ)}

- Entstehung und Ordnung biologischer Vielfalt.

- Systematik und Taxonomie.

Der Punkt dieser Arbeit ist es, Ordnung in die biologische Vielfalt zu bringen. Die Entstehung dieser Vielfalt geht auf eine Jahrmillionen lange Entwicklung zurück. In meinem Unterrichtsbeispiel gehe ich etwas darauf ein. Verwandtschaftsverhältnisse in einzelnen Organismengruppen aufzuklären ist eine wichtige Methode, um die Entwicklung einer geographischen Region nachzuvollziehen. Auf einer höheren Ebene natürlich auch, um die gesamte Evolution zu verstehen.

\section{Klasse}

- Zytologische und molekulare Grundlagen der Vererbung.

- Evolutionsmechanismen; chemische und biologische Evolution, Evolutionstheorien. 
- Evolution als Basis für die Vielfalt der Organismen und für den Wandel von Ökosystemen, Organen und zellulären Strukturen.

Phylogenetische Studien beschäftigen sich im Detail mit den Zusammenhängen zwischen Vererbung, Genetik auf der einen und Evolution und Biogeografie auf der anderen Seite. Es gibt viele verschiedenen Mechanismen der Vererbung, die zur Veränderung von Arten führen.

- Biotechnologische Verfahren, deren Anwendung und mögliche Auswirkungen; Wissenschaftsund Bioethik.

Gerade in der Phylogenetik werden oft modernste genetische Verfahren für die Datenerhebung angewendet. Das reicht von der PCR über AFLP-Fingerprinting, Genomsequenzierung, Genomgrößemessung wie in dieser Studie bis hin zu Next-GenerationSequencing in großangelegten Studien (Lexer et al., 2013).

\section{Fachdidaktische Ausarbeitung für den Unterricht}

Will man seine Umwelt verstehen, ist es immer gut, sich ihre Entstehungsgeschichte vor Augen zu führen. Wahrscheinlich kann man aus jedem Klassenzimmer in Tirol die Berge sehen. Den SuS erscheint es möglicherweise trivial, dass im Tal Landwirtschaft, dann an den Hängen Wald, oben freie Flächen, Almen und Wiesen anschließen und schließlich das Hochgebirge, möglicherweise mit ein paar schroffen Felsen und Graten, die Landschaft abrundet. Österreich ist ein Binnenland, jeder weiß das. Kein Meer weit und breit, warum sollte man sich dafür interessieren? Auf ein Menschenleben haben die geologischen Gegebenheiten auch keine unmittelbare Wirkung. Denkt man jedoch in evolutiven Zeiteinheiten, wird es schnell relevant, wie diese Landschaft entstanden ist. Es drängt sich etwa auf, dass nur die Zentralalpen aus Silikatgestein bestehen und diese nördlich und südlich von Sedimentgestein in Form der Kalkalpen flankiert werden. Man muss sich fragen: wie kommt Sediment an einen Ort, wo eigentlich Sediment abgetragen werden sollte? Naheliegend ist der Schluss, dass nicht immer Berge waren, wo jetzt Berge sind. Bleibt die Frage, warum dann jetzt? Und wie sind sie da hingekommen. Antworten liefert ein Blick zurück in die Vergangenheit.

Diese Stunde wurde für die 10. Schulstufe vorbereitet, wie oben schon beschrieben, zum Themenschwerpunkt: Aufbau und Struktur der Erde, geodynamische Formungskräfte. Der erste Teil mit der geologischen Zeitskala könnte, etwas detaillierter, z.B. mit dezidierten Organismengruppen, auch in der 11 . Schulstufe durchgenommen werden. 
Essenziell für das Verständnis von Biogeografie und Evolution ist ein Verständnis für die relativ junge Theorie über Plattentektonik (Lomolino et al., 2010) Die Erde hat - über Jahrmillionen gesehen - eine recht dynamische Geschichte. Plattentektonik spielt dabei eine tragende Rolle.

\section{Unterrichtseinheit}

Formales: 10. Schulstufe (6. Klasse) einer AHS. Sommersemester. 50min pro Schulstunde. Die einzelnen Stunden sind als Drehbuch gestaltet.

Ziel der Einheiten:

- Dies SuS erkennen, dass die Welt nicht in 7 Tagen erschaffen wurde.

- Die SuS erkennen, wie komplex die Welt um sie herum ist.

- Die SuS erkennen, dass sich das Leben auf Erden aufgrund wechselnder Umweltbedingungen immer wieder drastisch geändert hat.

- Die SuS können die Erdgeschichte von der Entstehung bis zur Jetztzeit grob gliedern.

- Die SuS können Abbildungen mit komplexen Inhalten in Worte fassen.

- Die SuS können Phänomene in ihrer Umgebung erdgeschichtlich einordnen und benennen. Vor allem die Entstehung der Alpen und spezielle Felsformationen. 


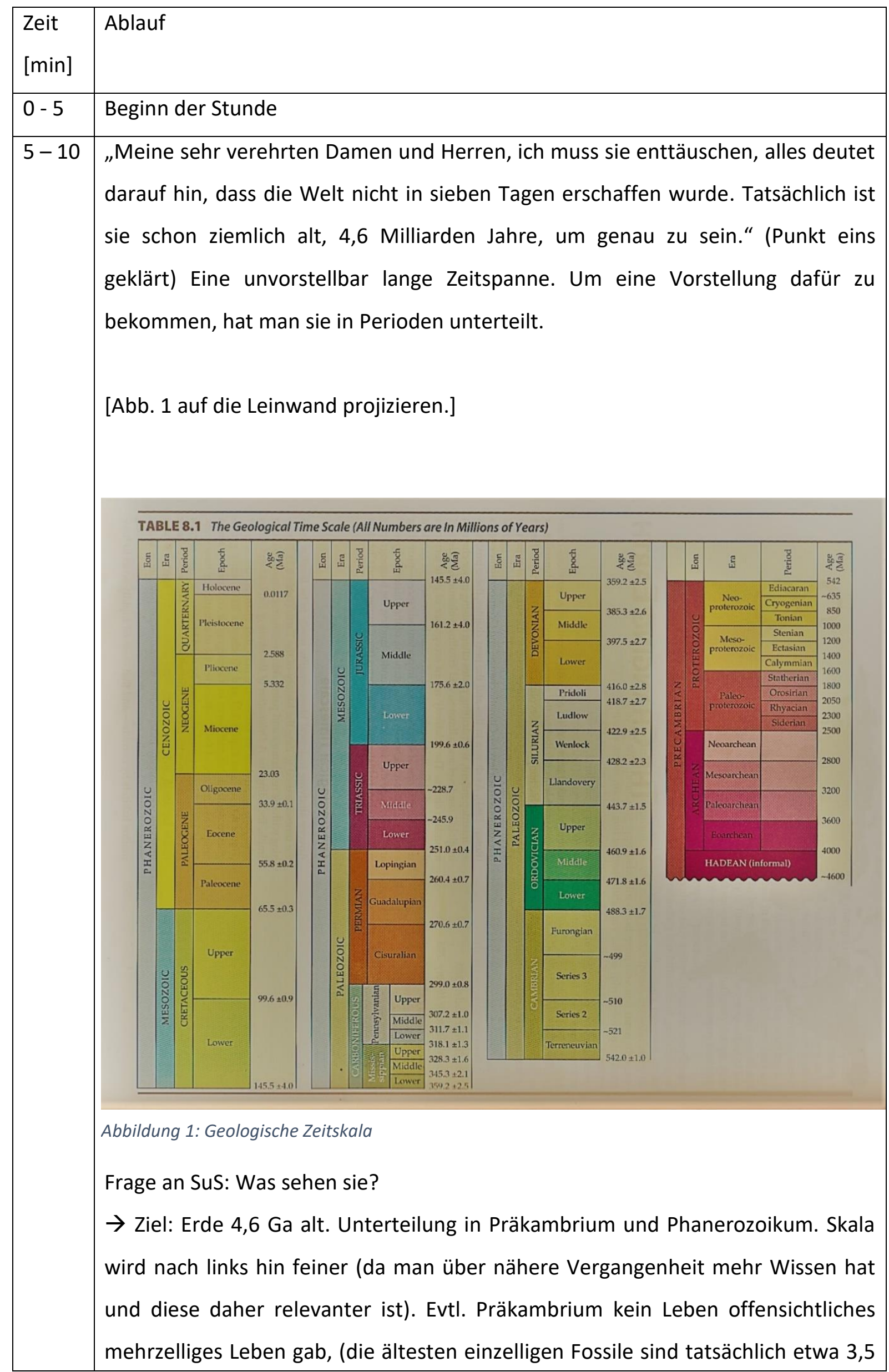




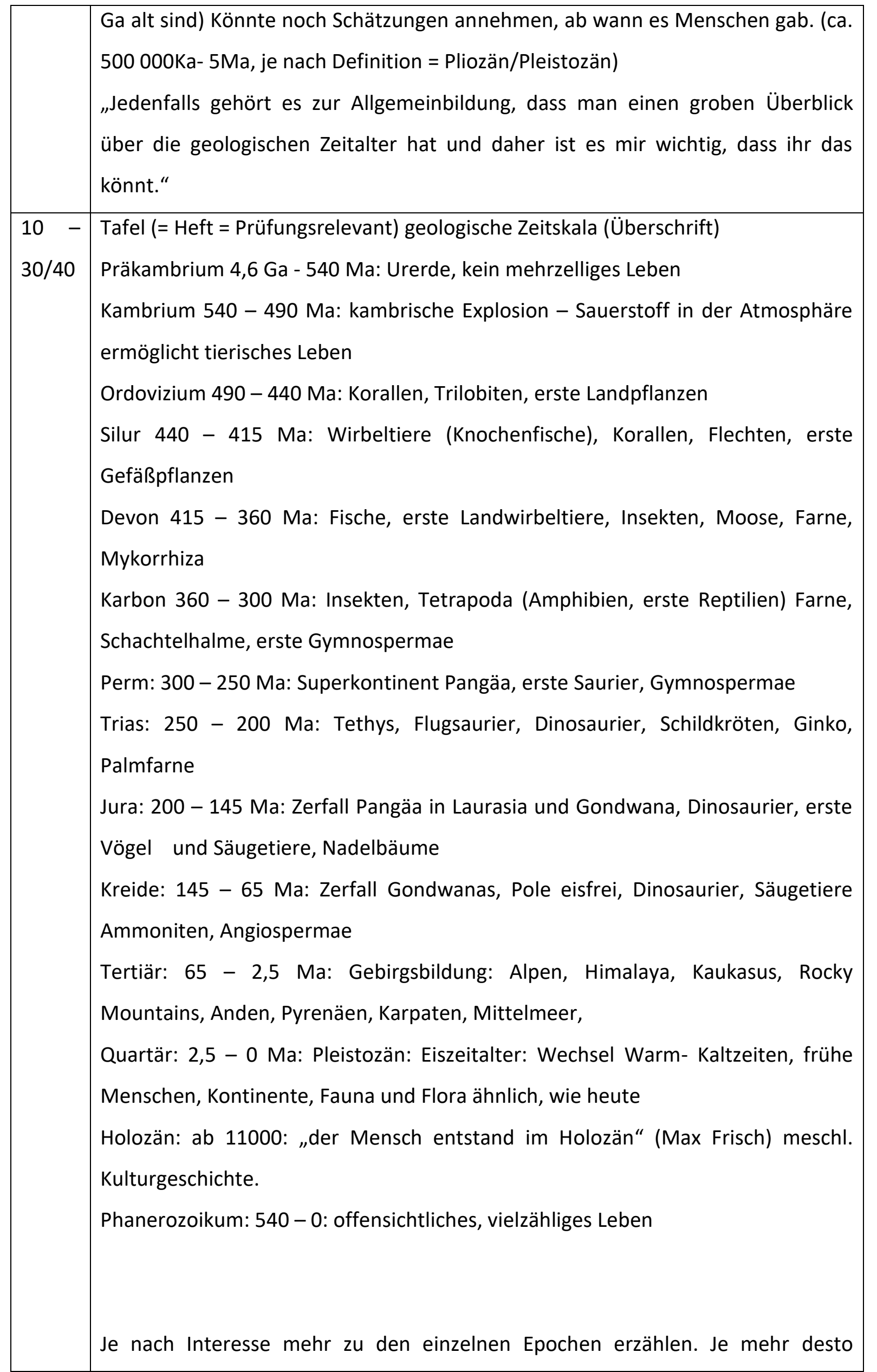




\begin{tabular}{|c|c|}
\hline & Quelle: Wikipedia \\
\hline $30 / 40$ & 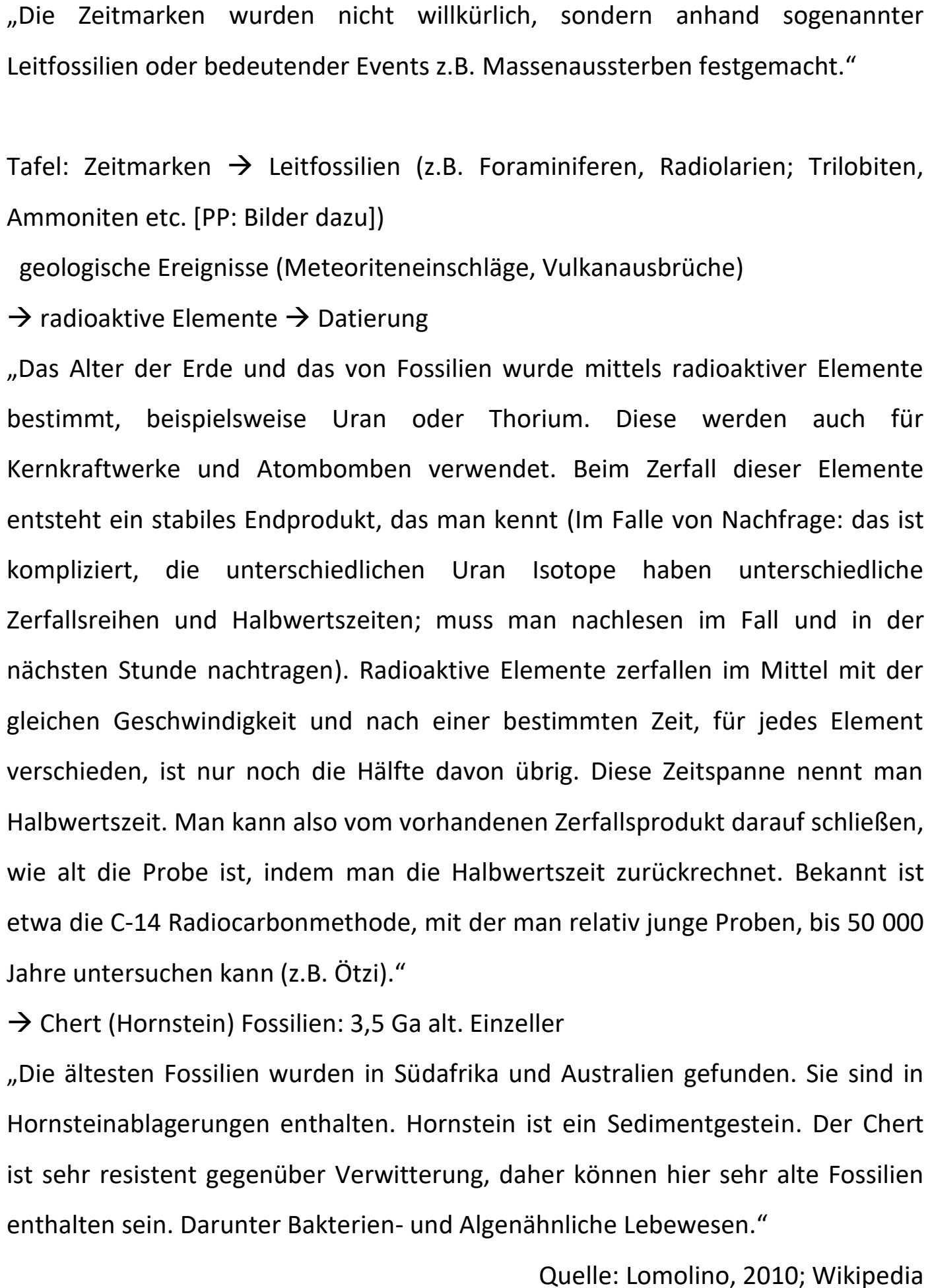 \\
\hline
\end{tabular}




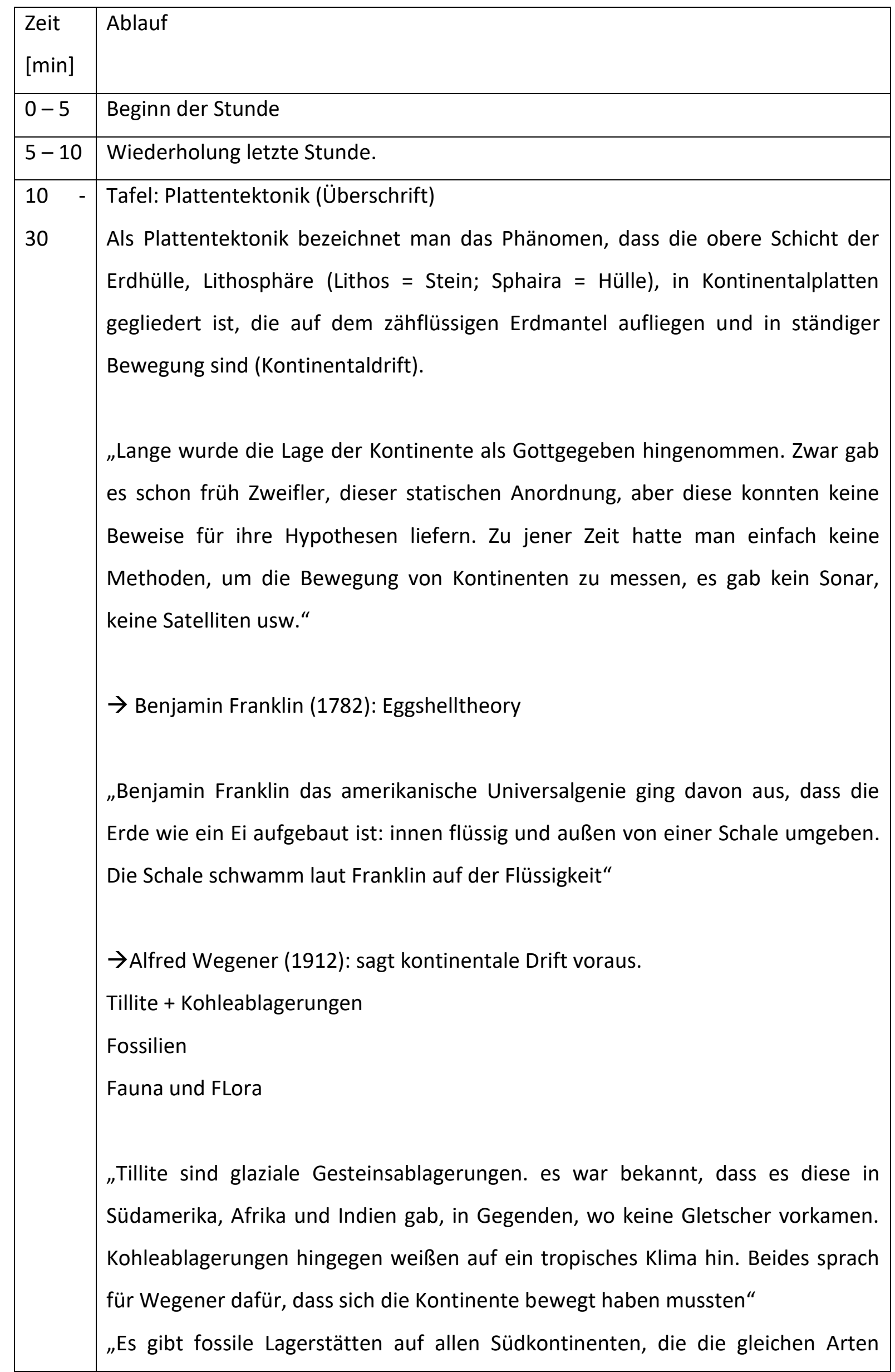




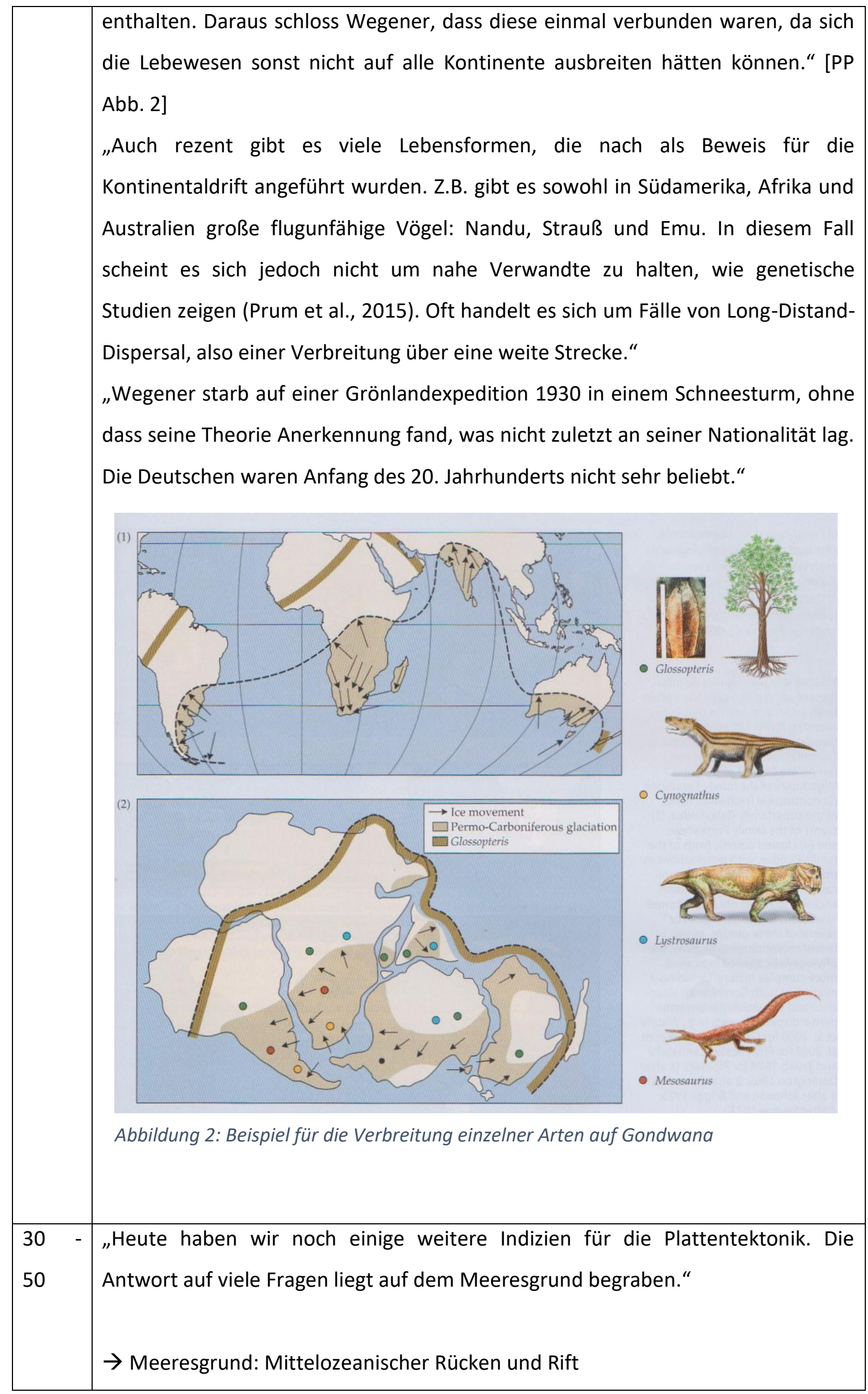


„Die Ozeane sind durchzogen von Gebirgsketten [PP Abb. 3]. Diese Erkenntnis machte man während des zweiten Weltkrieges, als man begann die Meere zu kartieren, um sie für U-Boote sicherer zu machen. Diese Gebirgsketten wiederum sind durchzogen von Gräben - Rift genannt -denen ständig heißes Gestein aus dem Erdinneren entströmt. Dieses Gestein kühlt aus und schiebt den restlichen Meeresboden vor sich her. Dieses Phänomen nennt man Seafloor-Spreading"

\section{$\rightarrow$ Seafloor Spreading}

$\rightarrow$ Paleomagnetismus: magnetische Streifen

„Auf der Abbildung kann man gut erkennen, dass das Gestein in der Mitte der Ozeane relativ jung ist und selbst am Rand ist es höchstens $140 \mathrm{Ma}$ alt. Die Kontinente hingegen sind im Schnitt 3,5 Ga alt. Die Massenbewegungen in den Rifts sind der Motor der kontinentalen Drift. Solche Rifts gibt es nicht nur unter Wasser. In Ostafrika gibt es den großen Grabenbruch. Dort bricht der Kontinent gerade auseinander."

„An den Rändern der Ozeane verschwindet der Meeresboden wieder im Erdinneren. Diese Zonen nennt man Tiefseegräben. Verbunden mit der Kollision von Meeresboden und Kontinentaler Kruste ist ein verstärkter Vulkanismus und

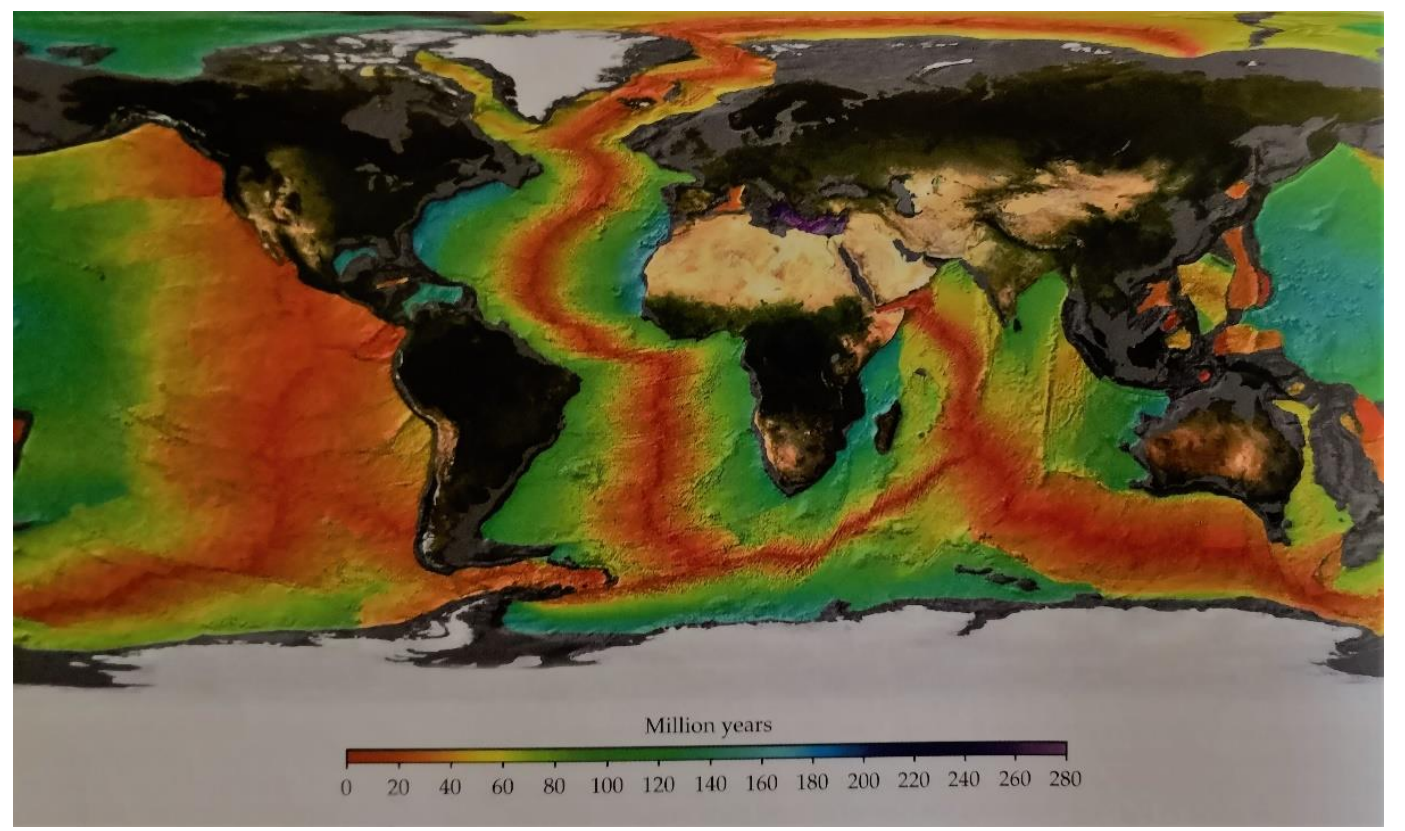

Abbildung 3: Seafloorspreading 


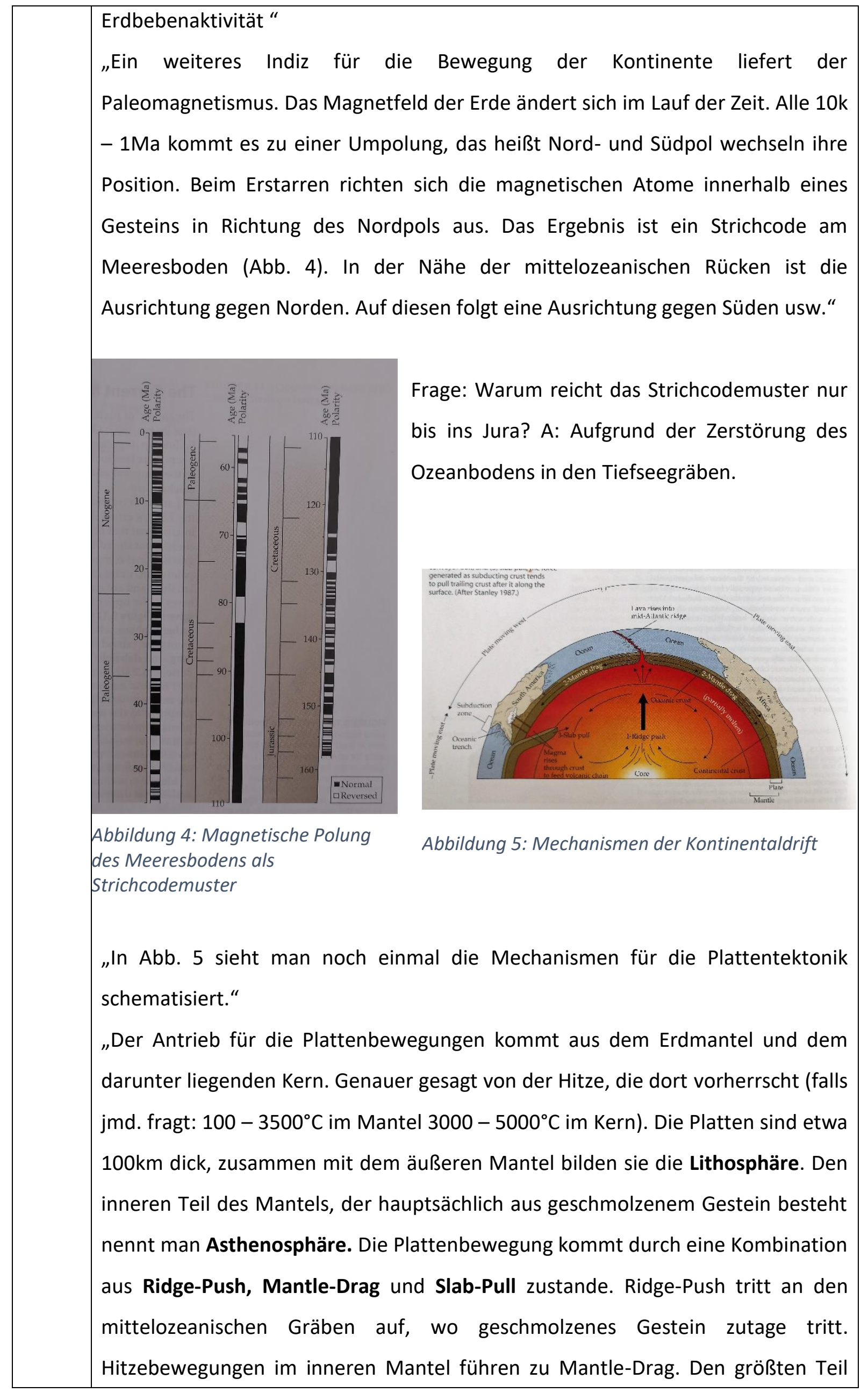




\begin{tabular}{|l|l|}
\hline der Arbeit scheinen jedoch die Subduktionszonen zu leisten, in denen die Platten \\
wieder ins Erdinnere gezogen werden. An Subduktionszonen gibt es meist auch \\
$\begin{array}{l}\text { Vulkanismus und häufige Erdbeben.“ (markierte Ausdrücke auf die Tafel } \\
\text { schreiben) }\end{array}$ \\
\hline
\end{tabular}

\section{Stunde - Plattentektonik und zeitliche Entwicklung}

\begin{tabular}{|c|c|}
\hline $\begin{array}{l}\text { Zeit } \\
{[\mathrm{min}]}\end{array}$ & Ablauf \\
\hline $0-5$ & Begi \\
\hline $5-10$ & holung letzte Stunde. Einstieg bei Abb. 5 . \\
\hline $\begin{array}{l}10- \\
20 / 30\end{array}$ & $\begin{array}{l}\text { zbbildung 6: Kontinentalplatten der Erde } \\
\text { Thineading } \\
\text { zone } \\
\text { Strike-slip fault } \\
\text { wiedererkennt und welche plattentektonischen Phänomene euch dazu einfallen. } \\
\text { Kennt ihr bestimmte Gebiete auf der Erde, die mit solchen Phänomenen im } \\
\text { Zusammenhang stehen? } 5-5-5 / 15 \text { min. } \\
\text { Hoffentlich genannt, sonst darauf hinweisen: alle großen Gebirge stehen an } \\
\text { Plattengrenzen (auf Karte zeigen). Platten können sich voneinander entfernen } \\
\text { (z.B. mittelozeanische Rücken, aber auch Rift Valley), kollidieren (z.B. Alpen, } \\
\text { Himalaya) oder an einander entlangschrammen (z.B. Pazifische P. und } \\
\text { Nordamerikanische P.). }\end{array}$ \\
\hline
\end{tabular}




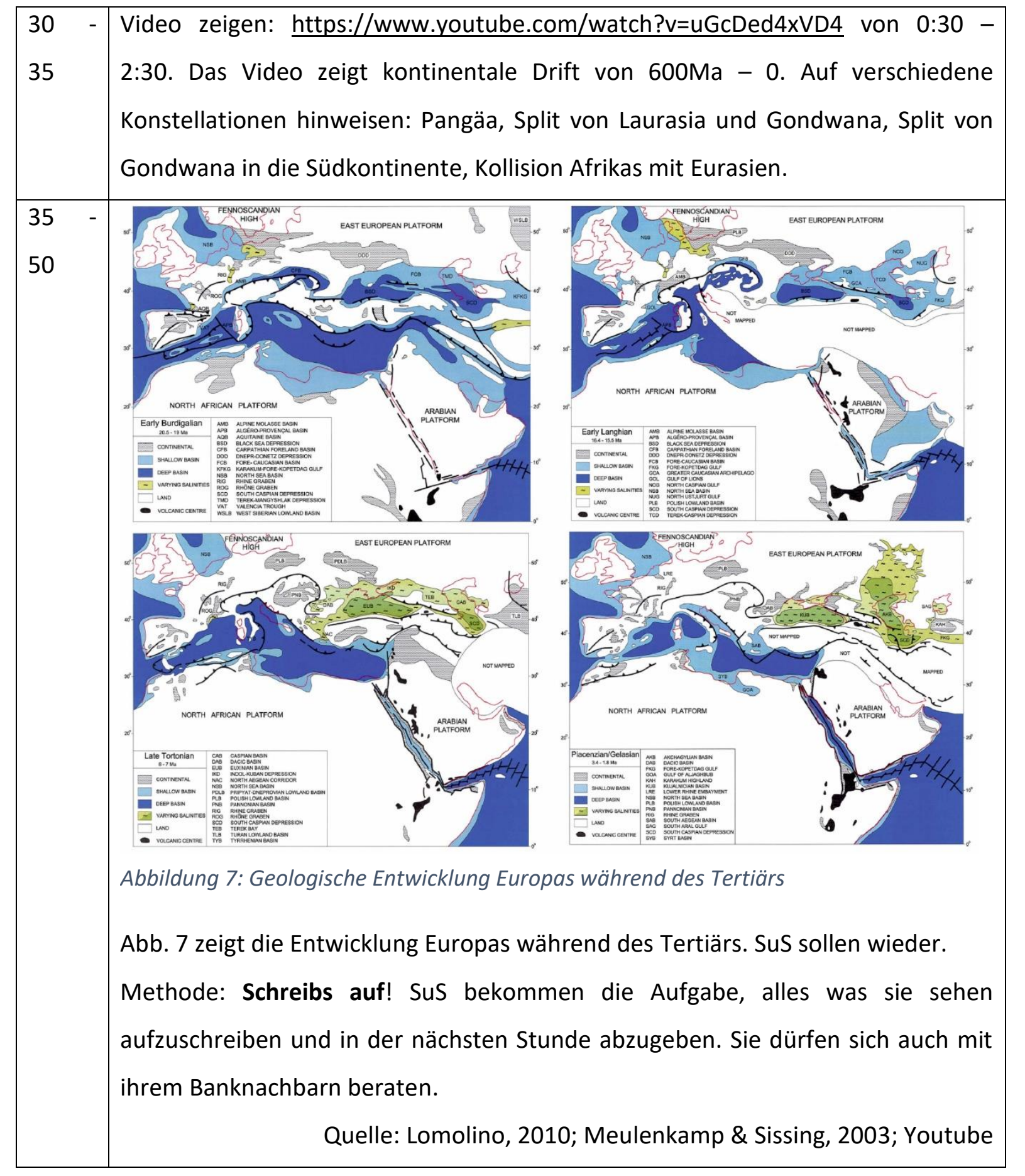

\section{4.+ 5. Stunde - Exkursion}

\begin{tabular}{|c|c|}
\hline $\begin{array}{l}\text { Zeit } \\
\text { [min] }\end{array}$ & Ablauf \\
\hline $\begin{array}{l}0 \\
100\end{array}$ & $\begin{array}{l}\text { Es braucht eine Doppelstunde } \\
\text { Die Exkursion ist von jedem Punkt in Tirol durchführbar, die Themen müssen } \\
\text { dementsprechend angepasst werden. } \\
\text { Zentrale Themen: Geografie, Klima und Geologie des Alpenbogens. Aufbauend }\end{array}$ \\
\hline
\end{tabular}


auf die zu vorigen Stunden kann man das Tethys Meer aufgreifen und so die Kalkablagerungen erklären. Vereinfacht kann man die Kalkablagerungen als Platte darstellen. Durch die Kollision mit Afrika entstand eine Subduktionszone, bei der die afrikanische Platte unter die eurasische Platte gedrückt wurde. Dadurch wurde die europäische Platte nach oben gehoben und die Alpen entstanden. Die Kalkplatte brach auseinander und Teile davon lagerten sich nördlich und südlich des Hauptkammes ab.

Überall in Tirol findet man glaziale Formationen. Seien es die Mittelgebirge, abgerundete Berggipfel, U-Täler, Findlinge etc. Diese kann man dazu nutzen, um das Eiszeit Thema aufzunehmen.

Daraus leitet man über auf Vegetationsgeschichte: Durch die Eiszeiten wurden viele Arten aus den Gebirgen verdrängt. Diese konnten in Refugien überdauern. Nach der letzten Eiszeit (Würm-Eiszeit), deren Höhepunkt vor ca. 20 Ka war, wurden die Alpen wieder besiedelt.

Die ersten Einwanderer waren Kiefer und Birke, gefolgt von der Haselnuss. es folgten Ulme und Eiche. Relikte von Hasel-Eichen-mischwäldern findet man noch an einigen Südexponierten Lagen, z.B. oberhalb von Ötz oder bei Mötz. Schließlich kamen auch andere, anspruchsvollere Baumarten, erst Erle und Fichte, dann auch Buche, Hainbuche und Tanne, die die Eichenwälder verdrängten.

Im Grunde kann man zu jeder Pflanze eine Geschichte erzählen, ja nach Interesse, Vorwissen und Aufnahmefähigkeit der SuS ist das abzuwägen.

Es sollte immer wieder Gelegenheit für die SuS geben, selbstständig ihre Umgebung zu erkunden. Je älter die SuS werden, desto weniger Motivation zeigen sie erfahrungsgemäß in dieser Hinsicht, daher macht es mehr Sinn, das Naturerlebnis mit Geschichten aufzulockern. Es ist jedenfalls wichtig, den SuS lebendes Material in die Hände zu geben und sie auf Besonderheiten hinzuweisen.

Quelle: Bresinsky et al., 2008 


\section{Quellen didaktischer Teil}

\section{Literatur}

Avise, J.C., 2000. Phylogeograpy: the history and formation of species. Harvard University Press, Cambridge, London.

Brecht, R.D., 2015. Erkenne die Welt, 4th ed. Wilhelm Goldmann, München.

Brecht, R. D. (2015) Erkenne die Welt. 4th edn. München: Wilhelm Goldmann.

Bresinsky, A., Körner, C., Kadereith, J.W., Neuhaus, G., Sonnewald, U., 2008. Strasburger: Lehrbuch der Botanik, 36th ed. Spektrum, Heidelber.

Dobzhansky, T., 1937. Genetics and the Origin of Species. Columbia Univerity Press, New York.

Donoghue, M.J., 2008. A phylogenetic perspective on the distribution of plant diversity. Proc. Natl. Acad. Sci. 105, 11549-11555. https://doi.org/10.1073/pnas.0801962105

Lexer, C., Mangili, S., Bossolini, E., Forest, F., Pearman, P.B., Zimmermann, N.E., Salamin, N., Gardens, R.B., 2013. 'Next generation' biogeography: towards understanding the drivers of species diversification and persistence 1013-1022. https://doi.org/10.1111/jbi.12076

Lomolino, M. V., Riddle, B.R., Whittaker, R.J., Brown, J.H., 2010. Biogeography, 4th ed. Sinauer, Sunderland.

Magauer, M., Schönswetter, P., Jang, T.S., Frajman, B., 2014. Disentangling relationships within the disjunctly distributed Alyssum ovirense/A.wulfenianum group (Brassicaceae), including description of a novel species from the north-eastern Alps. Bot. J. Linn. Soc. 176, 486-505. https://doi.org/10.1111/boj.12214

Meid, V., 2012. Das Reclambuch der Deutschen Literatur, 3rd ed. Philipp Reclam, Stuttgart.

Meulenkamp, J.E., Sissingh, W., 2003. Tertiary palaeogeography and tectonostratigraphic evolution of the Northern and Southern Peri-Tethys platforms and the intermediate domains of the African-Eurasian convergent plate boundary zone. Palaeogeogr. Palaeoclimatol. Palaeoecol. 196, 209-228. https://doi.org/10.1016/S0031-0182(03)00319-5

Poulakakis, N., Kapli, P., Lymberakis, P., Trichas, A., Vardinoyiannis, K., Sfenthourakis, S., Mylonas, M., 2015. A review of phylogeographic analyses of animal taxa from the aegean and surrounding regions. J. Zool. Syst. Evol. Res. 53, 18-32. https://doi.org/10.1111/jzs.12071 
Schönswetter, P., Stehlik, I., Holderegger, R., Tribsch, A., 2005. Molecular evidence for glacial refugia of mountain plants in the European Alps. Mol. Ecol. 14, 3547-3555. https://doi.org/10.1111/i.1365-294X.2005.02683.x

\section{Abbildungen}

Abbildungen 1-6:

Lomolino, M. V., Riddle, B.R., Whittaker, R.J., Brown, J.H., 2010. Biogeography, 4th ed. Sinauer, Sunderland.

Abbildung 7:

Meulenkamp, J.E., Sissingh, W., 2003. Tertiary palaeogeography and tectonostratigraphic evolution of the Northern and Southern Peri-Tethys platforms and the intermediate domains of the African-Eurasian convergent plate boundary zone. Palaeogeogr. Palaeoclimatol. Palaeoecol. 196, 209-228. https://doi.org/10.1016/S0031-0182(03)00319-5

\section{Onlinequellen}

https://bildung.bmbwf.gv.at/schulen/unterricht/Ip/lp ahs oberstufe.html (17.02.2019

https://www.youtube.com/watch?v=uGcDed4xVD4 (17.02.2019)

https://de.wikipedia.org/wiki/Wikipedia:Hauptseite (17.02.2019) 